OPEN ACCESS

Edited by:

Chandrabose Selvaraj,

Alagappa University, India

Reviewed by:

Antoine Dufour,

University of Calgary, Canada

Pitter F. Huesgen,

Helmholtz Association of German

Research Centres (HZ), Germany

F. Xavier Gomis-Rüth,

Institute of Molecular Biology of

Barcelona (CSIC), Spain

Salvatore Pizzo,

Duke University, United States

*Correspondence:

Jennifer Vandooren

jennifer.vandooren@kuleuven.be

Specialty section:

This article was submitted to

Cytokines and Soluble

Mediators in Immunity,

a section of the journal

Frontiers in Immunology

Received: 27 October 2021 Accepted: 29 November 2021 Published: 14 December 2021

Citation:

Vandooren $J$ and ltoh $Y$ (2021)

Alpha-2-Macroglobulin in Inflammation, Immunity and Infections.

Front. Immunol. 12:803244.

doi: 10.3389/fimmu.2021.803244

\section{Alpha-2-Macroglobulin in Inflammation, Immunity and Infections}

\author{
Jennifer Vandooren ${ }^{1 *}$ and Yoshifumi Itoh ${ }^{2}$ \\ 1 Laboratory of Immunobiology, Department of Microbiology, Immunology and Transplantation, Rega Institute for Medical \\ Research, Katholieke Universiteit (KU) Leuven, Leuven, Belgium, ${ }^{2}$ Kennedy Institute of Rheumatology, University of Oxford, \\ Oxford, United Kingdom
}

Alpha-2-macroglobulin is an extracellular macromolecule mainly known for its role as a broad-spectrum protease inhibitor. By presenting itself as an optimal substrate for endopeptidases of all catalytic types, alpha-2-macroglobulin lures active proteases into its molecular cage and subsequently 'flags' their complex for elimination. In addition to its role as a regulator of extracellular proteolysis, alpha-2-macroglobulin also has other functions such as switching proteolysis towards small substrates, facilitating cell migration and the binding of cytokines, growth factors and damaged extracellular proteins. These functions appear particularly important in the context of immune-cell function. In this review manuscript, we provide an overview of all functions of alpha-2-macroglobulin and place these in the context of inflammation, immunity and infections.

Keywords: alpha-2-macroglobulin, proteolysis, inflammation, immunity, infections, macrophages, neutrophils

\section{INTRODUCTION - THE MOLECULAR BASIS OF AN UNUSUAL PROTEASE INHIBITOR}

Alpha-2-macroglobulin (A2M) is a member of MEROPS clan I39 which has seven members in humans and two in mice. All of these proteins can interact with a broad range of endopeptidases. A2M in particular is considered an inhibitor of active endopeptidases of all catalytic types (1). This broad inhibition range stems from its unique mechanism of action. Whereas most protease inhibitors directly interfere with the protease active site, the inhibitory mechanism of A2M works through the formation of a tetrameric cage around active proteases, thereby physically obstructing the interaction between proteases and substrates. This mechanism is sometimes referred to as the protease 'snap-trap' or 'venus-flytrap' mechanism (2). As a consequence, proteases 'trapped' by A2M are prevented from cleaving large substrate molecules (e.g. collagen), while the digestion of small peptides (sneaking into the A2M cage) remains intact (3). The ability of A2M to selectively capture only active proteases, relies on the presence of a 'bait region', which is a stretch of amino acids functioning as an exceptionally good substrate for endopeptidases of all catalytic types (4-6). Upon proteolytic cleavage of the bait region by a protease, A2M becomes 'activated' (A2M*) and undergoes a conformational change, thereby 'trapping' active proteases within its tetrameric 
cage $(>720 \mathrm{kDa})$ (Figure 1). In addition to sterically capturing proteases, $\mathrm{A}_{2} \mathrm{M}^{*}$ also exposes a reactive thioester which interacts with small primary amines in the protease to form covalent $\mathrm{A} 2 \mathrm{M} /$ protease complexes (protease-A2 $\left.\mathrm{M}^{*}\right)(7,8)$. In vitro, small nucleophiles such as methylamine (MA) and other lowmolecular-weight primary amines are used to cause a conformational rearrangement of the tetramer that is likely similar to the peptidase induced form (9). We will abbreviate this form as $\mathrm{A}_{2} \mathrm{M}^{* *}$.

Another essential feature of A2M relies on the presence of the receptor binding domains (RBDs, Figure 1) that allow A2M to bind specific cell surface receptors. In native $\mathrm{A} 2 \mathrm{M}$, the RBDs are buried within the protein. However, during the conformational rearrangements associated with the transition into $\mathrm{A}_{2} \mathrm{M}^{*}$, the RBDs are exposed onto the surface of the protease-A2M* complex. Consequently, this 'flags' protease-A2M* complexes for uptake by cells through low density lipoprotein receptor-related protein-1 (LRP-1) (10). In human blood, binding of protease-A2M* complexes to LRP-1 is thought to result in rapid clearance by the liver and provides another level of protease regulation by A2M (11). In addition, this domain is also thought to bind cell surface glucoseregulated protein (GRP)78, also called binding immunoglobulin protein $(\mathrm{BiP})$ or heat shock $70 \mathrm{kDa}$ protein 5 (HSPA5) $(12,13)$, thereby triggering several cell signaling pathways (see chapter on the endocytic and signaling receptors).

Since the first discoveries of $\mathrm{A} 2 \mathrm{M}$ as a moderator of proteolysis, broader functions for $\mathrm{A} 2 \mathrm{M}$ have been proposed, including the enhancement of immune and cancer cell migration and proliferation $(13,14)$, the promotion of antigen uptake, processing and presentation by antigen presenting cells $(15,16)$, the ability of A2M to function as a carrier molecule for cytokines and growth factors $(17,18)$ and the removal of damaged extracellular proteins (19). In this review manuscript, we place $\mathrm{A} 2 \mathrm{M}$ in the context of the immune system and defense against invading microorganisms. We discuss the significance of A2M in neutrophil, monocyte/macrophage and lymphocyte biology, and its relevance in inflammatory diseases and infections.

\section{A2M AND THE COMPLEMENT SYSTEM}

The complement system is a key part of the immune system that comprises an evolutionarily ancient component of the host defense. Central to this system is the cleavage of complement factors (C3 and C4), followed by conformational changes and the exposure of an internal thioester which binds hydroxyl or amino groups of neighboring glycoproteins proteins (Figure 2A). This process marks malignant cells for removal (opsonization) or generates new protein complexes dedicated to further activate the complement cascade (21). Several striking parallels between $\mathrm{A} 2 \mathrm{M}$ and the complement system exist. Similar to C3 and C4, $\mathrm{A} 2 \mathrm{M}$ undergoes proteolysis, a conformational change and exposes an internal thioester which binds and traps active protease (22). Hence, together with C3 and C4, A2M is classified as a member of the thioester-containing proteins (TEPs). Similarly, the A2M family of proteins (A2Ms, MEROPS clan I39) can be separated into two classes; the protease inhibitors and the complement factors (23). In addition, also a membrane associated member of the A2M family (CD109) exists (Figure 2B) (24). Interestingly, it is thought that C3 evolved from a gene duplication of A2M (20) and that all A2Ms evolved from a core structure of eight homologous domains (24). Indeed, comparison of the molecular models of A2M and C3 illustrates considerable similarities between both proteins (Figure 2C). For a comprehensive overview of the evolutionary origins of $\mathrm{A} 2 \mathrm{M}$ and their structure and function the reader is referred to a manuscript by GarciaFerrer et al. (25).

In Limulus polyphemus (the Atlantic horseshoe crab), A2M acts as a protease inhibitor and, once activated, as an inhibitor of the haemolytic mechanism in Limulus haemolymph. A2M binds

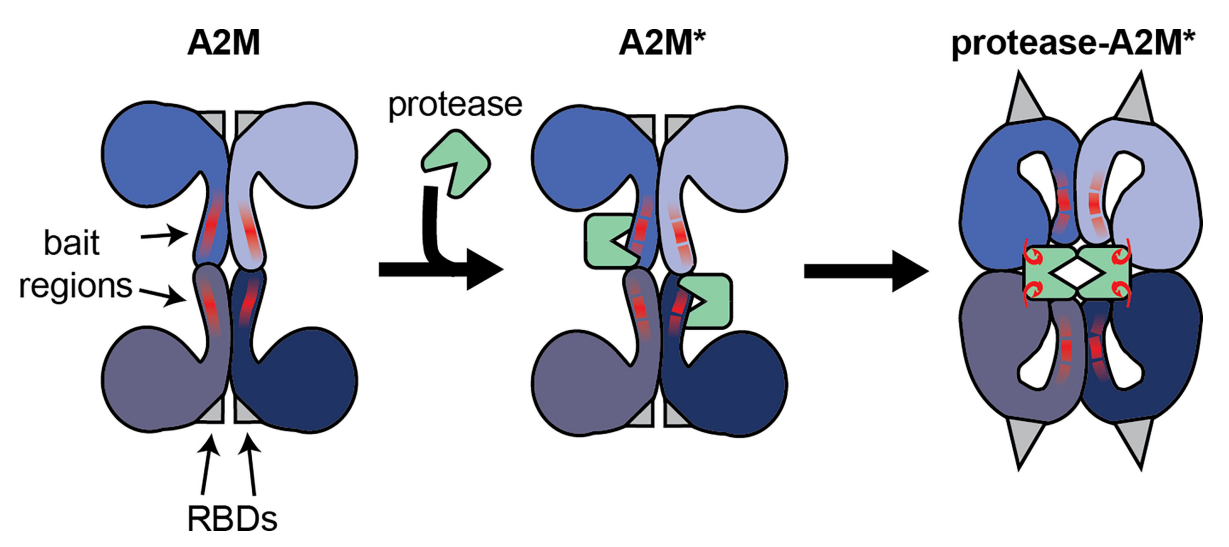

FIGURE 1 | Illustration of the interaction between the A2M tetramer and active endopeptidases. Functional A2M is formed by a non-covalent interaction between two covalently linked dimers. Each monomer contains a protease bait region (red lines) and a buried receptor binding domain (RBDs, gray triangles). Active proteases can cleave the bait region, resulting in $\mathrm{A} 2 \mathrm{M}$ activation ( $\left.\mathrm{A} 2 \mathrm{M}^{*}\right)$ and conformational rearrangement. This process results in physical trapping of the protease and the exposure of a reactive thioester bond which may result in the formation of a covalent bond between $\mathrm{A} 2 \mathrm{M}$ and protease lysine residues (red hooks). Simultaneously, the receptor binding domains are exposed to the protein surface, thereby enabling $\mathrm{A} 2 \mathrm{M}^{\star}$ to bind its cell-surface receptors. 


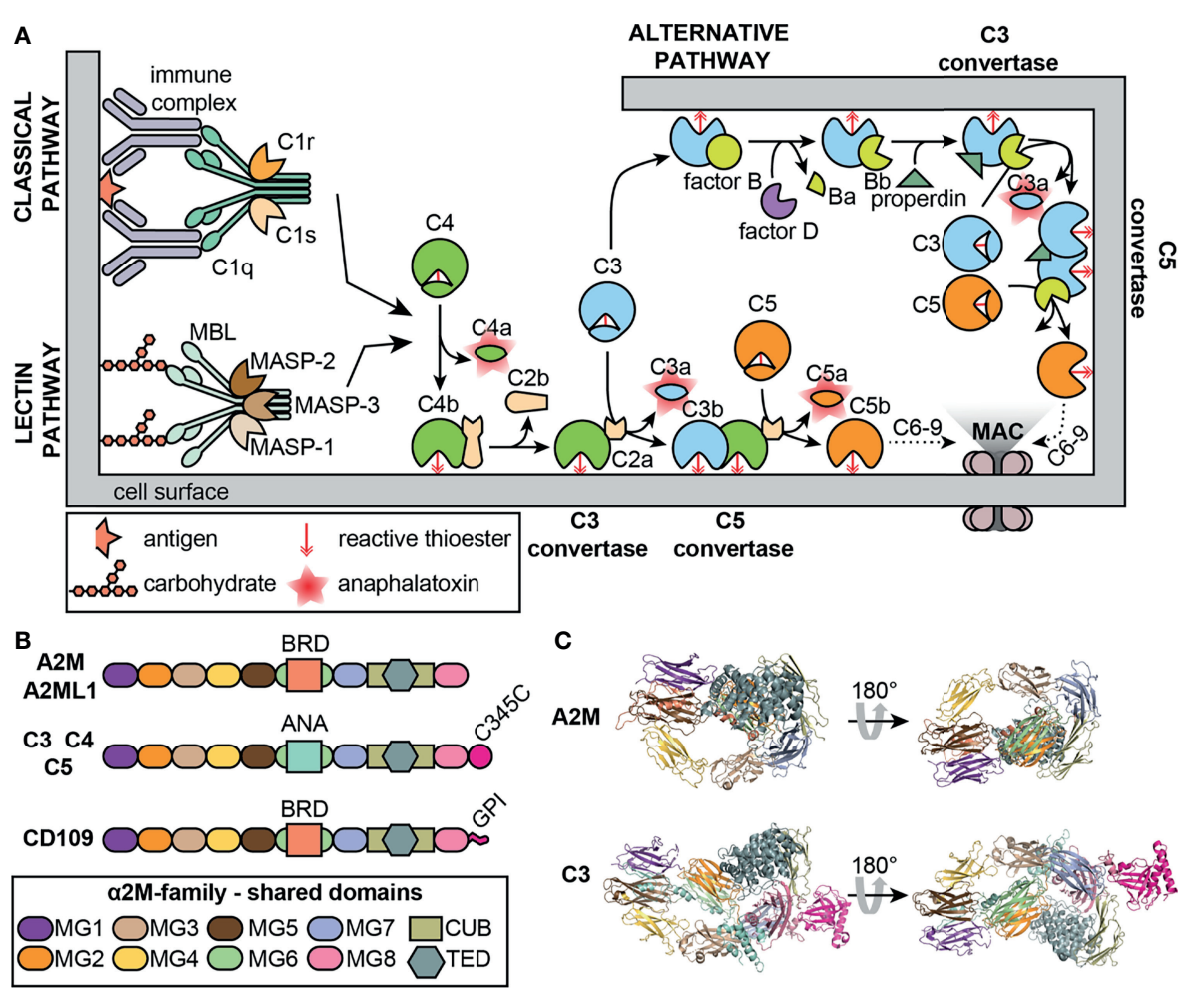

FIGURE 2 | The complement system and A2M. (A) Overview of the classical, lectin and alternative complement pathways. MAC, membrane attack complex; MASP, mannose-binding protein-associated serine protease; MBL, mannose-binding lectin. (B) Overview of the domain organization of a selection of human proteins belonging to the A2M family (MEROPS protease inhibitor family I39). A2ML1, A2M-like-1; ANA, anaphylatoxin domain; BRD, bait-region domain; C345C, C-terminal extension of C3-5; CUB, complement C1r/C1s, Uegf, Bmp1; GPI, glycosyl-phosphatidyl-inositol linker; MG, macroglobulin-like domains; TED, thioester domain. (C) comparison of the crystal structures of the A2M monomer (PDB structure: 4ACQ) (2) and C3 (PDB structure: 2A73) (20). Domain colors are based on the colors used in Panel (B) For A2M, part of the bait region and the MG8/RBD are not shown.

to erythrocyte surfaces and it was speculated whether it could act as an opsonin $(22,26-28)$. Therefore, it is tempting to wonder if $\mathrm{A} 2 \mathrm{M}$ - being an ancestral thioester-containing protein - might have acted as the initial "opsonic" system, activated by proteases derived from invading organisms (e.g. virulence factors) and subsequently binding to the protease-producing organism $(1,29$, 30). A main difference, however, between A2M and complement components is that the latter are secreted as monomeric proteins whereas human A2M forms a tetrameric structure, permitting physical entrapment of active proteases (29).

Several direct interactions between human A2M and proteins of the complement system have also been discovered. In human serum, a complex was found between mannose-binding protein (MBP), MBP-associated serine protease (MASP, a protease with complement activation activity in the lectin pathway) and $\mathrm{A} 2 \mathrm{M}$, suggesting a regulatory role for $\mathrm{A} 2 \mathrm{M}$ in the lectin pathway of the complement cascade (Figure 2A) (31). Furthermore, direct inhibitory activity of A2M on MASPs was shown and others suggested that $\mathrm{A} 2 \mathrm{M}$ is mainly an inhibitor of the ancient type protease MASP-1, whereas inhibition of MASP-2 is less efficient (32). An interaction between A2M and MASP-1 was also confirmed by Paréj et al., however, in this study A2M could not abolish lectin pathway activation (33). Also, a direct interaction between $\mathrm{MBL}$ and $\mathrm{A} 2 \mathrm{M}$ was suggested $(34,35)$. When screening for human and mouse serum proteins with the capacity to bind to mannan-binding lectin (MBL), A2M was identified. This interaction occurred through the direct binding of $\mathrm{MBL}$ carbohydrate recognition domains to oligomannose glycans $\mathrm{Man}_{5-7}$ present at $\mathrm{Asn}^{846}$ on A2M. This binding site remains accessible both on $\mathrm{A} 2 \mathrm{M}$ and $\mathrm{A} 2 \mathrm{M}^{*}$, and binding of $\mathrm{MBL}$ to A2M hardly interferes with the ability of MBL to bind mannan-coated surfaces. Interestingly, in the same study C3 and C4 were also identified as MBL-binders. Finally, it was suggested that an ancestral (glycosylated) A2M-like TEP might have generated "arrays" of oligomannose glycans on the surface of microorganisms through inhibition of cell surface proteases. Subsequently, MBL or other lectins could bind to the oligomannose layer, leading to opsonization and activation of the complement system (35). In a recent study, A2M was also identified as the possible antigen causing hexamerization/ aggregation of IgG as seen in patients with chronic lymphocytic leukemia and chronic activation of the complement classical pathway. A2M was found to be part of the IgG hexamer complex and present at the cell surface of malignant B lymphocytes through binding with GRP78 (36). The mechanism through which such interaction would occur 
remains to be determined. In conclusion, several separate studies have provided clues for some involvement of A2M in activation of the complement system. However, the overall relevance of these findings in a biological context or the contribution to pathological processes largely remains to be explored.

\section{BINDING TO CYTOKINES AND GROWTH FACTORS}

As early as the 1970s, researchers discovered that macrophage activation factors and nerve growth factors were bound to A2M in human and mouse serum $(37,38)$. Next, many more cytokines and growth factors joined the list of A2M-binding proteins (see Table 1). Biochemical interaction studies revealed that most cytokines and growth factors preferentially bind proteaseactivated $\mathrm{A}_{2} \mathrm{M}^{*}$ or chemically activated $\mathrm{A} 2 \mathrm{M}^{* *}$. For example, transforming growth factor (TGF)- $\beta 1\left(K_{D}=80 \pm 11 \mathrm{nM}\right)$, nerve growth factor (NGF)- $\beta\left(K_{D}=0.11 \pm 0.01 \mathrm{uM}\right)$, fibroblast growth factor (FGF)-2 $\left(K_{D}=0.59 \pm 0.04 \mathrm{uM}\right)$ and tumor necrosis factor (TNF) $-\alpha\left(\mathrm{K}_{\mathrm{D}}>0.75 \pm 0.10 \mathrm{uM}\right)$ have increased binding affinity for $\mathrm{A}_{2} \mathrm{M}^{* *}$ and reach their binding equilibrium within 15 minutes. As an exception, TGF- $\beta 2$ binds both forms equally well $\left(K_{D} \pm 12 \mathrm{nM}\right)(40,41,55,64)$.

Based on competition experiments it was suggested that several binding sites for cytokines and growth factors exist and that these also depend on the A2M conformation. For example, FGF competes with TGF- $\beta$, but not platelet-derived growth factor (PDGF), for binding to A2M (41, 55). All PDGFisoforms $(\mathrm{AA}, \mathrm{BB} \& \mathrm{AB})$ compete for binding to $\mathrm{A} 2 \mathrm{M}$ and $A 2 \mathrm{M}^{* *}$. However, they do not compete for native A2M with TGF- $\beta 1$, TGF- $\beta 2$, TNF- $\alpha$, FGF2, interleukin (IL)-1 $\beta$ and IL-6, whereas for $\mathrm{A} 2 \mathrm{M}^{\star *}$ PDGF competes with TGF- $\beta 1$ and FGF2 (50). Similarly, it was shown that vascular endothelial growth factor (VEGF) does not compete with TGF- $\beta 1$ or PDGF (62). TGF- $\beta 1$ competes for the binding of FGF- 2 to A2M and A2M** (39). In addition, A2M only binds certain members of the FGFfamily, including FGF-1, -2, -4 and -6 , but not FGF-5, -7, -9 or -10 (39).

The nature of the interaction between A2M and cytokines/ growth factors can be both non-covalent and covalent. Most often, initial complexes between $\mathrm{A}_{2} \mathrm{M}^{* *}$ and cytokines/growth factors are non-covalent and reversible, and are slowly converted into covalent interactions (40) (Table 1). Generally three mechanisms for A2M/cytokine/growth factor binding have been proposed; (i) non-covalent interaction through trapping in the A2M molecular cage, (ii) covalent interaction through thiol-disulphide exchange with a free thiol-group exposed upon $\mathrm{A} 2 \mathrm{M}$ activation, (iii) covalent binding via the active thioester group, exposed upon protease activation of A2M (28). Interestingly, for some growth factors, an A2M-binding region was identified. A $20 \mathrm{kDa}$ protein, comprising the A2M bait region and neighbouring sequences (amino acids 614-797), could interact with TGF- $\beta 1$, TGF- $\beta 2$, PDGF-BB and NGF- $\beta$ (56). This sequence could also neutralize TGF- $\beta 1$ and TGF- $\beta 2$ activity in endothelial cell proliferation assays (fetal bovine heart cells) (56) and the binding of PDGF-BB to PDGF receptors on fibroblasts (NIH 3T3 cells) (49). Subsequently the growth factor binding site (for TGF- $\beta 1$ and PDGF-BB) was narrowed down to a 16-amino acid peptide (WDLVVVNSAGVAEVGV), containing a high proportion of hydrophobic amino acids (51) and within this sequence one glutamic acid residue was shown to be crucial for binding to PDGF-BB (and not TGF- $\beta 1$ ) (52).

For many cytokines/growth factors, the functional implications of binding to A2M remain unknown (18). One possibility is that $\mathrm{A} 2 \mathrm{M}$ serves as a reservoir for cytokines and growth factors, and increases their half-life (18). For IL-8/A2 $\mathrm{M}^{\star *}$ complexes it was shown that IL- 8 retained its potential to induce neutrophil chemotaxis and complexation rendered IL-8 less sensitive to proteolysis by neutrophil elastase (NE) (48). However, when analyzing the plasma clearance of TGF- $\beta 1$, TGF- $\beta 1 / A 2 M^{\star}$ and TGF- $\beta 1 / A 2 M^{\star \star}$ complexes administered to mice, the complexes were efficiently cleared from the circulation through liver uptake $\left(\mathrm{t}_{1 / 2}\right.$ of $\left.4 \mathrm{~min}\right)$, whereas free TGF- $\beta 1$ was also found in the lungs (58). This difference in clearance could be explained by receptor-mediated uptake of TGF- $\beta 1 / \mathrm{A} 2 \mathrm{M}^{*}$ complexes through interaction of the RBDs with LRP-1 (58). However, other researchers showed that blocking of the clearance receptor by excess administration of $\mathrm{A}_{2} \mathrm{M}^{\star *}$ did not affect the half-life of TGF- $\beta 1$ and that endogenous TGF- $\beta 1$ is mainly bound to native A2M (65). Similarly, TNF- $\alpha /$ plasmin$\mathrm{A}_{2} \mathrm{M}^{*}$ complexes injected into mice were efficiently cleared and this clearance could be stopped by blocking the A2M-receptor (61). The same was true for PDGF-BB/A2 $\mathrm{M}^{* *}$ complexes (54). These findings indeed suggest a role for $\mathrm{A} 2 \mathrm{M}$ in cytokine regulation and the net effect might be context-dependent. For example, under physiological conditions, cytokines and growth factors might bind native $\mathrm{A} 2 \mathrm{M}$ and remain in circulation. In contrast, under conditions with high protease activity, proteolysis of $\mathrm{A} 2 \mathrm{M}$ and conversion into $\mathrm{A} 2 \mathrm{M}^{*}$, results in rapid clearance of $\mathrm{A} 2 \mathrm{M}^{*} /$ cytokine/growth factor complexes. Unfortunately, in vivo evidence to support this hypothesis is limited.

Another possible impact of A2M complex formation is the modulation of growth factor/cytokine-receptor interactions and their associated functions. It was reported that TGF- $\beta$ and $\mathrm{A} 2 \mathrm{M}^{\star *}$ work synergistically to promote proliferation of cultured smooth muscle cells (SMCs) (60). However, in another study, A2M reduced the ability of TGF- $\beta 2$ to inhibit lung cell proliferation (CCL-63 mink lung cell line), whereas the activity of TGF- $\beta 1$ remained unaltered (64). In case of TNF- $\alpha$, the presence of $\mathrm{A}_{2} \mathrm{M}^{* *}$ or plasmin- $\mathrm{A}^{*} \mathrm{M}^{*}$ did not affect its cytotoxic effects on cultured fibroblasts (mouse L929 cells) (61). FGF-2 incubation with $\mathrm{A}^{2} \mathrm{M}^{\star *}$ reduced FGF-2-induced endothelial cell proliferation. In contrast, interaction with $\mathrm{A}_{2} \mathrm{M}^{* *}$ did not affect vascular tubule formation on Matrigel basement membrane matrix or collagen, likely due to exchange of FGF-2 with extracellular matrix components (39). Hence, the inhibitory effect of $\mathrm{A} 2 \mathrm{M}^{* *}$ on FGF-2 function might be limited to the fluid phase and may serve to restrict FGF activity to sites of angiogenesis, inflammation, and tissue repair. 
TABLE 1 | A2M interaction with cytokines and growth factors.

\begin{tabular}{|c|c|c|c|}
\hline $\begin{array}{l}\text { Binding } \\
\text { partner }\end{array}$ & Proposed interaction & Biological significance and impact on cytokine/growth factor activity & ref. \\
\hline FGF1 & binds to $\mathrm{A} 2 \mathrm{M}$ and increasingly to $\mathrm{A} 2 \mathrm{M}^{\star *}$ & - & (39) \\
\hline FGF2 & $\begin{array}{l}\text { non-covalent contact with } \mathrm{A}_{2} \mathrm{M}^{* *} \text {, slowly converts into a } \\
\text { covalent interaction }\end{array}$ & $\begin{array}{l}\text { - } \quad \text { complex forms in human plasma } \\
\text { - } \quad \text { reduced binding to FGF-receptors (BHK-21 cells) } \\
\text { reduced ability to stimulate plasminogen activator production (bovine epithelial } \\
\text { - } \quad \text { A2M } \mathrm{M}^{* \star} \text { inhibits FGF-2-dependent fetal bovine heart endothelial cell proliferation } \\
\text { - } \quad \text { does not affect FGF-2-induced vascular tubule formation on Matrigel or collagen } \\
\text { matrix }\end{array}$ & $(39-41)$ \\
\hline FGF-4 & binds $\mathrm{A} 2 \mathrm{M}$, increased binding to $\mathrm{A} 2 \mathrm{M}^{\star \star}$ & - & (39) \\
\hline FGF-6 & binds $\mathrm{A} 2 \mathrm{M}$, increased binding to $\mathrm{A} 2 \mathrm{M}^{\star *}$ & - & (39) \\
\hline IFN- $\gamma$ & covalent binding to $\mathrm{A}_{2} \mathrm{M}^{\star *}$ and protease- $\mathrm{A}_{2} \mathrm{M}^{*}$ & $\begin{array}{l}\text { - } \quad \text { no impact on antiproliferative activity (bladder tumor cell line) } \\
\text { - } \quad \text { no influence on induction of MHC class II }\end{array}$ & $(42)$ \\
\hline IL-1 $\beta$ & 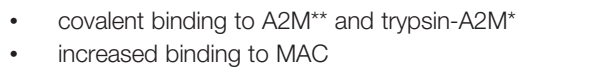 & $\begin{array}{l}\text { - } \quad \text { complex found in human plasma } \\
\text { - } \quad \text { L-1ß/A2M retains IL-1-like activity (mouse thymocytes) }\end{array}$ & $(43-45)$ \\
\hline IL-8 & non-covalent binding to $\mathrm{A} 2 \mathrm{M}^{\star *}$ & $\begin{array}{l}\text { - } \quad \text { IL-8/A2M isolated from lungs of ARDS patients } \\
\text { - } \quad \text { no effect on neutrophil chemotaxis } \\
\text { - } \quad \text { protects IL-8 from proteolysis }\end{array}$ & $(48)$ \\
\hline IL-18 & binds mostly to MAC & - & (44) \\
\hline NGF- $\beta$ & 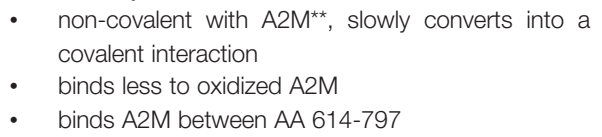 & - & $\begin{array}{l}(40,46 \\
49)\end{array}$ \\
\hline PDGF & $\begin{array}{ll}\text { - } & \text { non-covalent binding to } \mathrm{A}_{2} \mathrm{M}^{* *} \text {, slowly converts } \\
& \text { into a covalent interaction } \\
\text { - } & \text { binds less to oxidized A2M } \\
\text { - } & 2 \times \mathrm{PDGF} \text { per A2M } \\
\text { - } & \text { all isoforms bind native } \mathrm{A} 2 \mathrm{M} \text { and } \mathrm{A}_{2} \mathrm{M}^{* *} \\
\text { - } & \text { binds to the growth factor binding site }\end{array}$ & $\begin{array}{l}\text { - } \quad \text { complex found in human plasma } \\
\text { - } \text { retains mitogenic activity } \\
\text { - } \text { not detected by anti-PDGF antisera } \\
\text { - } \quad \text { clecks receptor binding } \\
\text { - } \quad \text { fusion protein containing the A2M binding site blocks binding to PDGF- } \beta \\
\text { receptor (NIH } 3 T 3 \text { cells) }\end{array}$ & $\begin{array}{l}(17,40 \\
49-54)\end{array}$ \\
\hline TGF- $\beta 2$ & 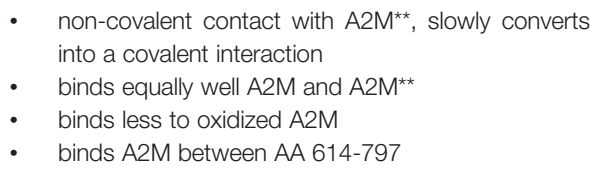 & $\begin{array}{l}\text { - } \quad \text { A2M inhibits binding to cell surface receptors } \\
\text { - } \quad \text { reduces the anti-proliferative activity of TGF- } \beta 1 \\
\text { protein containing the A2M binding site neutralizes TGF- } \beta 2 \text { activity in endothelial } \\
\text { cell proration assays (fetal bovine heart cells) }\end{array}$ & $(40,56)$ \\
\hline TNF- $\alpha$ & 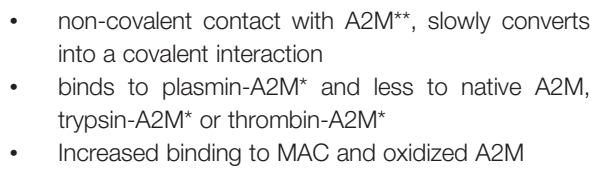 & $\begin{array}{l}\text { - TNF- } \alpha \text { binding to MAC suppresses inflammation by inhibition of MAPK p38 } \\
\text { - } \quad \text { TNF- } \alpha \text { retains cytotoxic effects on fibroblasts (L929 murine fibroblasts) } \\
\text { - } \quad \text { no effect on antiproliferative activity (bladder tumor cell line) }\end{array}$ & $\begin{array}{l}(40,42, \\
44,46 \\
61)\end{array}$ \\
\hline VEGF & $\begin{array}{l}\text { - covalent binding } \\
\text { - does not bind at growth factor binding site } \\
\text { binds the interior of } \mathrm{A}^{\mathrm{M}} \mathrm{M}^{* *} \text { and the exterior of } \\
\text { native and protease-activated } \mathrm{A}^{2} \mathrm{M}^{*}\end{array}$ & $\begin{array}{l}\text { - } \quad \text { reduced binding to VEGF receptor } \\
\text { VEGF/A2M** complexes are internalized and degraded by macrophages (LRP-1- } \\
\text { mediated) } \\
\text { - } A 2 M \text { does not impact VEGF-induced cell proliferation or } \mathrm{Ca}^{2+} \text { increases } \\
\text { (HUVECs). }\end{array}$ & $(62,63)$ \\
\hline
\end{tabular}

A2M*, protease-activated A2M; A2M**, A2M activated through reaction with low molecular-weight primary amines; $A$ A, amino acid; ARDS, adult respiratory distress syndrome; FGF, fibroblast growth factor; HUVECs, Human umbilical vein endothelial cells; IFN, interferon; IL, interleukin; MAC, A2M activated for cytokine binding; NGF, nerve growth factor; PDGF, platelet-derived growth factor; SMC, smooth muscle cell; TGF, transforming growth factor; TNF, tumor necrosis factor; VEGF, vascular endothelial growth factor. 
The preference of some cytokines/growth factors to bind $\mathrm{A} 2 \mathrm{M}^{\star} / \mathrm{A}_{2} \mathrm{M}^{* *}$ has been exploited by efforts to generate stable conformational intermediates of $\mathrm{A} 2 \mathrm{M}^{*} / \mathrm{A} 2 \mathrm{M}^{*}$ with optimized cytokine and growth factor binding capacities (66). Human $\mathrm{A} 2 \mathrm{M}$, treated with a cross-linking reagent to lock the A2M conformation and subsequently with methylamine, bound TGF- $\beta 1$ and TGF- $\beta 2$ with higher affinity than other A2M forms. This form successfully inhibited TGF- $\beta 1$-mediated inhibition of endothelial cell proliferation (66). Similarly, Webb (67) et al. generated a modified form of A2M named 'macroglobulin activated for cytokine binding' or MAC. MAC was formed through consecutive reactions with the amino acid side-chain crosslinker cis-dichlorodiammineplatinum-II and MA. MAC had increased binding affinity with the proinflammatory cytokines TNF- $\alpha$ and IL-1 $\beta$ (67). Administration of MAC (intraperitoneal) prior to lipopolysaccharide (LPS)challenge in mice (intravenous injection), increased the survival rate (67). In a model for peripheral nerve injury, MAC could also suppress inflammation. Hence, it has been suggested that MAC has an anti-inflammatory function through binding inflammatory cytokines (44). Interestingly, in a different study it was shown that oxidation of $\mathrm{A} 2 \mathrm{M}$ or $\mathrm{A} 2 \mathrm{M}^{* *}$ by hypochlorite (an oxidating agent secreted by neutrophils), increases the affinity of $\mathrm{A} 2 \mathrm{M}$ and $\mathrm{A}_{2} \mathrm{M}^{* *}$ for TNF- $\alpha$, IL-2, and IL- 6 , but decreases the affinity for $\beta$-NGF, PDGF-BB, TGF- $\beta 1$, and TGF- $\beta 2$. This implicates that oxidative modification of $\mathrm{A} 2 \mathrm{M}$ during inflammation might alter the repertoire of A2M-binding cytokines and growth factors (46). Interestingly, mice deficient in A2M have significantly lower levels of plasma TNF- $\alpha$ and develop a short-term attenuated fever in response to LPS administration. Therefore, it has been suggested that the A2M chemokine-binding capacities might be important for the development of fever (68).

\section{THE ENDOCYTIC AND SIGNALING RECEPTORS}

\section{LRP-1/the A2M Receptor/CD91}

LRP-1 (also called the A2M receptor or CD91) is a large, multifunctional receptor, composed out of a non-covalently bound $515-\mathrm{kDa}$ extracellular domain (also called the "heavy domain' or $\alpha$-chain) and an $85 \mathrm{kDa}$ transmembrane domain (also called the 'light chain' or $\beta$-chain) (Figure 3). These two domains are formed from a $600 \mathrm{kDa}$ precursor protein after cleavage by furin (69). After its biosynthesis, LRP-1 interacts with a $39 \mathrm{kDa}$ receptor-associated protein (RAP) which can also be found associated with LRP-1 at the cell surface (70). RAP efficiently blocks LRP-1 function and is therefore an endogenous regulator of LRP- 1 activity (71). The extracellular LRP-1 $\alpha$-chain holds four regions with cysteine-rich complement-type repeats (CR) (72), also referred to as clusters I-IV or ligand binding domains, and which are the main interaction interface for extracellular ligands. Clusters II and IV were identified as the most widely used interaction sites for LRP-1 ligands (73).

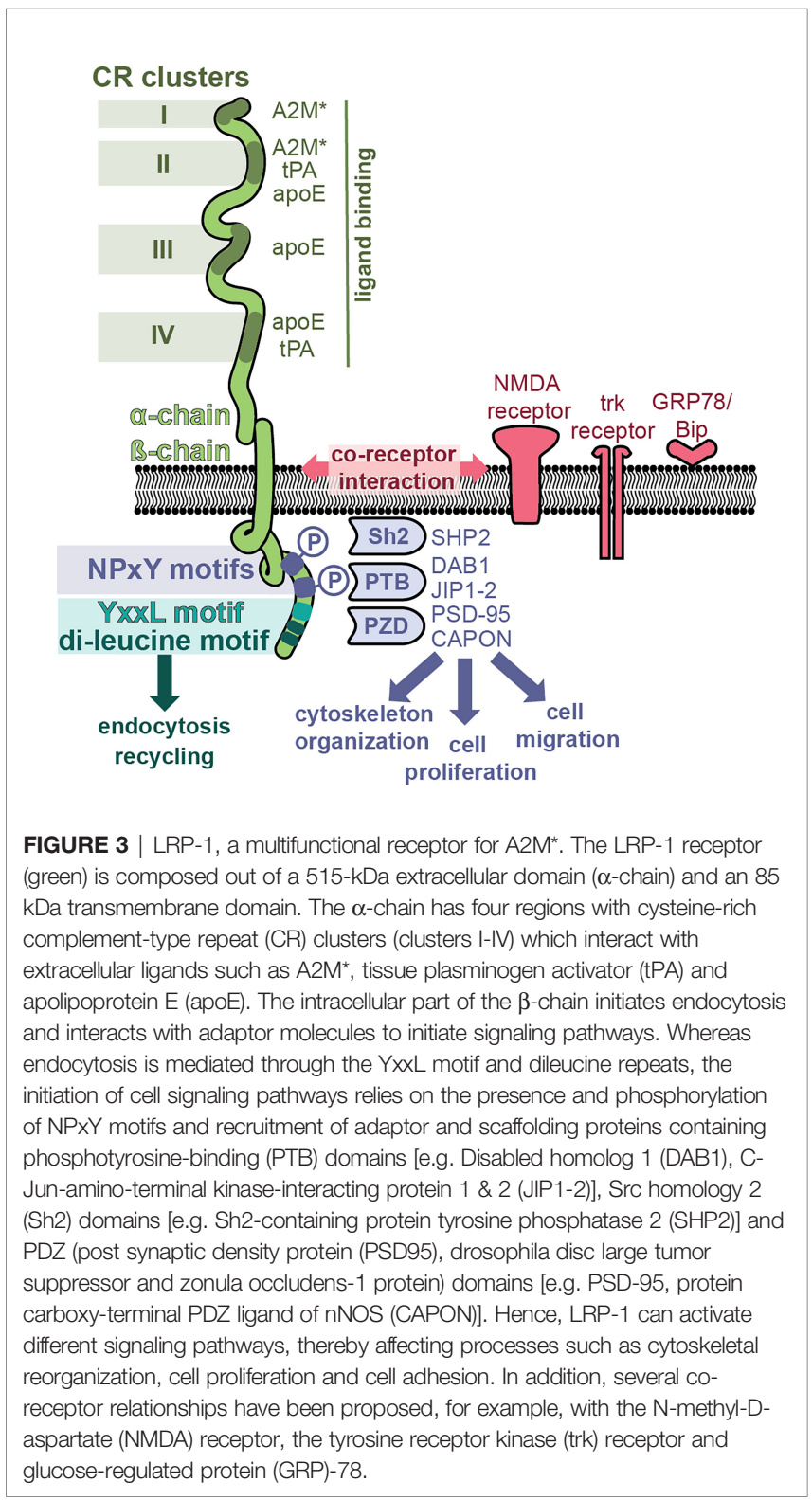

The best known function of LRP-1 is its role as a scavenging receptor for many proteins including protease, protease inhibitors, complement proteins and even toxins and viruses (74). After ligand binding, LRP-1 undergoes efficient endocytosis via clathrin-coated pits and subsequent recycling. This process is mainly mediated through the YxxL motif and dileucine repeats, present in the intracellular part of the LRP-1 $\beta$-chain (75) (Figure 3). Activated $\mathrm{A} 2 \mathrm{M}^{*}$ undergoes efficient cellular uptake through interaction with LRP-1. For example, in mouse fibroblasts (BaIb 3T3 cells), cellular uptake and presence of A2M in cytoplasmic vesicles occurs within 5 minutes, and after 15-30 minutes the content of these vesicles is found in the lysosomes (76). Upon proteolysis of the A2M bait region by active proteases or chemical activation, the $\mathrm{A} 2 \mathrm{M}$ receptor binding domains (RBD, Figure 1) are exposed, which form the interface between LRP-1 and A2M*/A2 $\mathrm{M}^{* *}$ (77). When 
evaluating variants of the receptor binding domain, two lysine residues (Lys ${ }^{1393}$ and $\mathrm{Lys}^{1397}$ ) in the $\mathrm{A} 2 \mathrm{M}$ receptor binding domain were found to be crucial for receptor binding (78-80). Moestrup (81) et al. found that trypsin-A2 $\mathrm{M}^{*}$ can bind with low $(\mathrm{kd}=2 \mathrm{nM})$ and with high $(\mathrm{kd}=40 \mathrm{pM})$ affinity to LRP-1 and proposed that binding efficiency depends on the availability of the receptor (receptor density). For example, at low receptor density only one subunit of the A2M tetramer will interact with one LRP-1, whereas at high receptor density two or more LRP-1 receptors will bind per A2M tetramer (81). Electron microscopy visualization showed that up to three LRP-1 receptors could bind to chymotrypsin-A2 $\mathrm{M}^{\star}(82)$. In addition, cooperative binding to several LRP-1 clusters has been reported, for example, A2M ${ }^{*}$ trypsin complexes cooperatively bind to cluster I and cluster II (83).

The LRP-1 $\beta$-chain also holds several signature sequences that connect LRP-1 with adaptor proteins involved in cell signaling and protein trafficking (84). Two NPxY domains are located in the C-terminal part of LRP-1 (Figure 3) and these provide binding sites for several adaptor and scaffolding proteins containing phosphotyrosine-binding (PTB) domains [e.g. disabled homolog 1 (DAB1), C-Jun-amino-terminal kinaseinteracting protein $1 \& 2$ (JIP1-2)] (84) or proteins containing Src homology 2 (Sh2) domains [e.g. Sh2-containing protein tyrosine phosphatase 2 (SHP2)] (85). In addition, also several adaptor proteins containing PDZ (post synaptic density protein (PSD95), drosophila disc large tumor suppressor and zonula occludens-1 protein) domains were found to bind the LRP-1 intracellular tail [e.g. PSD-95, protein carboxy-terminal PDZ ligand of nNOS (CAPON)] (84). Hence, LRP-1 has the potential to activate different signaling pathways, driving processes such as cytoskeletal reorganization, cell proliferation, apoptosis and cell adhesion (84). Interestingly, it appears that phosphorylation of the distal NPxY site is mostly involved in the interaction with signaling proteins, whereas the proximal phosphorylation site is more involved in the process of receptor recycling, suggesting non-redundant properties $(73,84,85)$.

Whereas the multifunctional potential of LRP-1 is clear, knowledge on how each of these pathways in triggered by different LRP-1 ligands and how LRP-1 selects among these pathways remains incomplete. One possible way is through the interaction with a co-receptor (86). For example, LRP1 functions as a single system with the N-methyl-D-aspartate (NMDA) receptor and tyrosine receptor kinase (trk) receptor, to activate cell signaling [extracellular signal-regulated protein kinase (ERK)-1/2] in response to tissue plasminogen activator (tPA) and $\mathrm{A}_{2} \mathrm{M}^{* *}$. In contrast, myelin-associated glycoprotein affects LRP-1 differently and results in recruitment of p75 neurotrophin receptor (p75NTR) into a complex with LRP-1 and activated Ras homolog family member A (RhoA) (86).

LRP-1 has generally low tissue specificity and is expressed ubiquitously, including in hepatocytes, neurons, astrocytes, epithelial cells of the gastrointestinal tract, SMCs, fibroblasts, Leydig cells in testis, granulosa cells in ovary, and dendritic interstitial cells of the kidneys (87). In addition, monocytes and macrophages express more LRP-1 (88). One method of LRP-1 regulation is proteolytic shedding of its ectodomain from the cell surface. Membrane-associated proteases including membranetype 1 matrix metalloproteinase (MT1-MMP) and a disintegrin and metalloprotease 17 (ADAM17) are capable of shedding LRP1 in chondrocytes (89) and the prevalence of soluble LRP-1 (sLRP-1) was shown to correlate with pro-inflammatory conditions (90). Following LPS injection, increases in sLRP can be found in mouse plasma. In conditions of chronic inflammation, increased levels of sLRP-1 have also been found (90). Interestingly, stimulation of macrophages with purified sLRP results in a pro-inflammatory effect and activation of nuclear factor kappa-light-chain-enhancer of activated B cells (NF- $\mathrm{BB}$ ), c-Jun N-terminal kinases (JNK) and p38 mitogenactivated protein kinases (p38 MAPK) (90). In contrast, other studies found anti-inflammatory functions for sLRP-1. For example, sLRP-1 could reduce the pro-inflammatory effects of TNF- $\alpha$ (91).

\section{GRP78/BiP/HSPA5}

LRP-1 was identified as the first receptor for activated A2M, but the evidence for a second receptor was published in 1994 by Misra (12) et al. In this study, the LRP-1 inhibitor RAP could not block $\mathrm{A}_{2} \mathrm{M}^{* *}$-mediated increases in intracellular calcium and inositol 1,4,6-triphosphate in macrophages, which led the authors to suggest the existence of a second receptor (12). The newly identified receptor functioned through a pertussis toxininsensitive G-protein and contrasts with LRP-1 mediated signaling, which occurs through a pertussis toxin-sensitive G protein $(12,92)$. From the membrane fraction of mouse macrophages and 1-LN prostate cancer cells, GRP78 $(78 \mathrm{kDa})$ was identified as the second A2M-receptor (13). This interaction was confirmed when purified GRP78 was found to bind A2M** with high affinity (Kd $\sim 150$ pM) (13). In addition, LRP-1 was copurified during this study, suggesting a co-receptor relationship between GRP78 and LRP-1 (13) (Figure 3).

Surprisingly, GRP78 is mainly known as an intracellular protein and member of the heat shock protein 70 (HSP70) family involved in correct translocation and folding of newly synthesized polypeptides across the endoplasmic reticulum membrane (93). Glucose-regulated proteins are induced under conditions of cellular stress, such as glucose starvation or agents affecting calcium stores or glycosylation patterns (94). Consequently, GRPs are typically increased in conditions involving tissue starvation and stress such as ischemia, vascular dysfunction, inflammation, apoptosis and necrosis. Under healthy conditions they are thought to protect against cell death, whereas the anti-apoptotic functions might also support the survival of neoplastic cells and their resistance to treatments (94-96). Based on co-immunoprecipitation in macrophage membrane fractions, it was shown that DnaJ homolog subfamily C member 1 (Dnajc1, also called MTJ-1) interacts with GRP78 at the cell membrane and enables cell-surface localization of GRP78 (97). Dnajc1 belongs to the family of J domain proteins (JDPs) which bind and activate Hsp70 proteins through their J domain (98). The interaction of GRP78 with Dnajc1 might thus explain the association of GRP78 with cell membranes. 
Functionally, it was shown that $\mathrm{A}^{2} \mathrm{M}^{\star *}$ signaling through GRP78 triggers pro-proliferative and anti-apoptotic behavior in macrophages and cancer cells (99). In prostate cancer cells, binding of $\mathrm{A}^{2} \mathrm{M}^{* *}$ to GRP78 causes an increase in prostatespecific antigen (PSA). PSA is secreted as an active serine protease which again binds and activates more A2M, resulting in a positive feedback loop where PSA-A2M* complexes bind GRP78, activate mitogen-activated protein kinase (MEK)-1/2, ERK1/2, S6 kinases S6, and Akt resulting in the promotion of DNA and protein synthesis and increased cell proliferation (100). A detailed overview of $\mathrm{A}_{2} \mathrm{M}^{*} / \mathrm{A} 2 \mathrm{M}^{* *}$ signaling through GRP78 on macrophages is provided in the next chapter.

\section{EFFECTS OF A2M ON LEUKOCYTES}

In this section we will discuss the effects of $\mathrm{A} 2 \mathrm{M}$ on leukocytes, specifically neutrophils, monocytes, macrophages, and lymphocytes. Generally, the roles of A2M in leukocyte biology relate to all previously mentioned aspects of $\mathrm{A} 2 \mathrm{M}$ function including inhibition of protease activity, binding of immunologically important molecules (e.g. cytokines/growth factors) and binding of cell-surface receptors for clearance or to trigger diverse pathways relevant for cell function.

\section{Neutrophils}

$\mathrm{A} 2 \mathrm{M}$ inhibits the activity of the main proteases released from stimulated human neutrophils (101), specifically NE (101-104), proteinase 3 (P3) (105), cathepsin G (catG) (101) and matrix metalloproteinase-9 (MMP-9) (106, 107). However, inhibition of total neutrophil proteolysis - in in vitro assays with isolated neutrophils or their full degranulates - is often incomplete (102, 103). For example, only $73.5 \%$ of fibronectin proteolysis by neutrophils can be inhibited by A2M (102). Several explanations for this phenomenon have been proposed. First, proteases trapped by $\mathrm{A} 2 \mathrm{M}$ remain functionally active against substrates that can access the interior of the A2M molecular cage (104). For example, in bronchoalveolar lavage fluid from patients with adult respiratory distress syndrome, NE activity against a low molecular weight substrate could be measured despite a 30fold excess of the anti-proteases alpha-1-antitrypsin and A2M. Whereas most NE was complexed to these inhibitors, NE activity against small substrates could be associated with NE-A2M* complexes (104). Second, as part of the antimicrobial host defense, stimulated neutrophils produce and release a range of reactive oxygen species (ROS) which act by oxidizing and modifying biological components. Therefore, it was suggested that neutrophils inactivate A2M by the release of reactive species such as hypochlorite. Through oxidative modification, ROS affect A2M structural integrity and cause dissociation of A2M tetramers into dimers which do not possess anti-proteolytic activity (108-111) (Figure 4). Finally, certain proteases partially escape regulation by A2M. For example, MMP-9, a metalloproteinase secreted from neutrophil specific granules, is produced as both a monomeric and homotrimeric form. In contrast to monomeric MMP-9, trimeric MMP-9 is able to

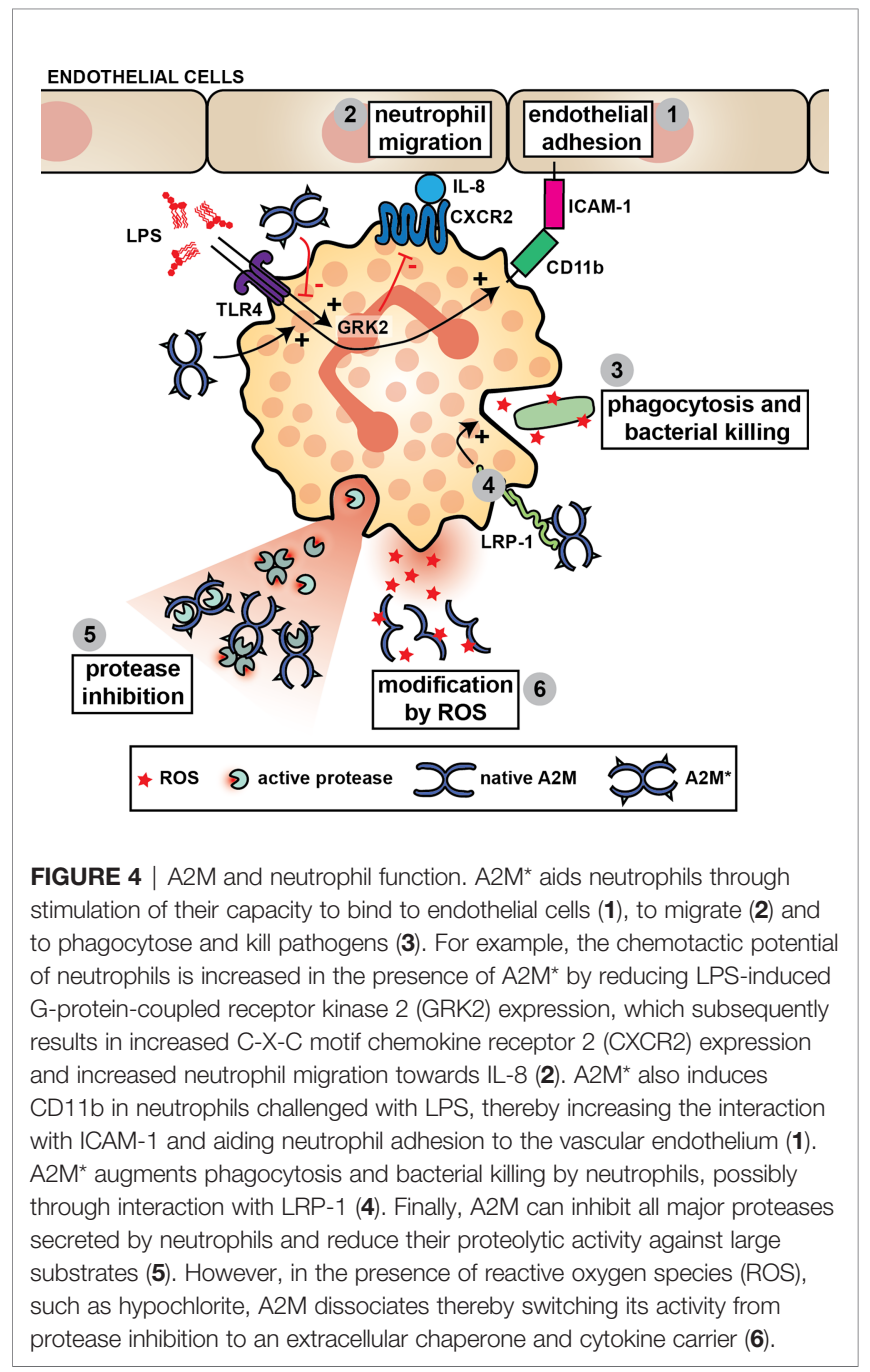

bind $\mathrm{A} 2 \mathrm{M}$ and remain active against large substrates, likely due to its size difference (107) (Figure 4).

Whereas ROS such as neutrophil-derived hypochlorite might revoke the ability for A2M to capture and inhibit proteolytic enzymes, other important implications recently have been discovered. First, hypochlorite alters the cytokine/growth factor binding profile of $\mathrm{A} 2 \mathrm{M}$ and $\mathrm{A}_{2} \mathrm{M}^{* *}$ (46). This modification increases the affinity of A2M and A2M** for TNF- $\alpha$, IL-2, and IL- 6 , but decreases binding to $\beta$-NGF, PDGF-BB, TGF- $\beta 1$, and TGF- $\beta 2$. Hence, it was proposed that oxidation would decrease the progression of acute inflammation by sequestering TNF- $\alpha$, IL-2, and IL-6, while up-regulating the development of tissue repair processes by releasing factors important for healing (46). Second, it was shown that A2M exposed to hypochlorite dissociates into stable dimers with potent chaperone activity for damaged proteins. For example, hypochlorite-induced dimers efficiently inhibit heat-induced aggregation of creatine phosphokinase and citrate synthase. Furthermore, these dimers also bind amyloid $\beta$-peptide $(\mathrm{A} \beta 1-42)$ and facilitate its removal through lipoprotein receptors, thereby reducing neurotoxicity $(112,113)$. Once converted to $\mathrm{A}^{2} \mathrm{M}^{\star}$ by reaction with proteases, 
these complexes undergo efficient receptor-mediated uptake (e.g. by monocyte/macrophage RAW 264.7 cells), thereby avoiding the build-up of toxic protein aggregates $(112,114)$.

In human neutrophils, LRP-1 is found at the cell surface as well as intracellularly. Upon stimulation with LPS, LRP-1 is mobilized from intracellular stores to the cell surface, which suggests a role for LRP-1 in anti-microbial defense (115). Interestingly, A2M is also a major component of neutrophilderived microparticles. In a proteomics study of neutrophilderived microparticles, microparticles of human umbilical vein endothelial cell (HUVEC)-adhering neutrophils were found to be enriched in A2M (116). In the presence of active A2M, LPSchallenged neutrophils increasingly expose the adhesion and migration marker CD11b. This results in increased interaction with ICAM-1, likely increasing neutrophil adhesion to vascular endothelium (Figure 4). Likewise, A2M is thought to improve the capacity of endothelial cells to interact with neutrophils. Pretreatment of TNF- $\alpha$-stimulated HUVECs with A2Menriched microparticles or microcapsules also results in an increase in neutrophil adhesion onto the endothelial cell monolayer $(115,117)$. No difference in the expression of endothelial adhesion molecules was found, but it was suggested that $\mathrm{A} 2 \mathrm{M}$ is delivered onto the endothelial cells plasma membranes where it engages LRP-1 on the neutrophils promoting firm leukocyte adhesion (115).

In vitro, $\mathrm{A} 2 \mathrm{M}$ enhances the migration of polymorphonuclear cells towards neutrophil-derived eosinophil chemotactic factor (118). Activated A2M quickly (1h stimulation) reduces LPSinduced G-protein-coupled receptor kinase 2 (GRK2) and increases CXCR2 leading to increased migration of LPSstimulated neutrophils towards IL-8 (115). In agreement with these findings, administration of $\mathrm{A} 2 \mathrm{M}$ microvesicles prior to a cecal ligation puncture (CLP) procedure in mice (as a model for polymicrobial sepsis) resulted in an increase of early (6h) neutrophil recruitment (115). Hence, this confirms that A2M is chemokinetic in neutrophils (119).

Finally, A2M has also been implicated in neutrophil phagocytosis and bacterial killing. A2M binds to the surface of Streptococcus pyogenes (groups A, C and G) $(120,121)$. So far, the identified protein interaction partners are either the N-terminal region protein $\mathrm{G}$ (groups $\mathrm{C}$ and $\mathrm{G}$ ) (122) or the protein G-related A2M-binding protein (GRAB) (group A) (123). Whereas earlier studies report that binding of A2M to S. pyogenes enhances its phagocytosis by human neutrophils (124), more recent studies propose that $S$. pyogenes-bound $\mathrm{A} 2 \mathrm{M}$ protects this bacteria against host proteases and is thus a virulence factor in $S$. pyogenes infections. In a separate study, neutrophils pre-treated with activated $\mathrm{A} 2 \mathrm{M}$ or $\mathrm{A} 2 \mathrm{M}$-enriched microparticles, had an increased capacity to phagocytose E. coli and produced increased amounts of ROS and bactericidal cathelicidins, a process which was LRP-1-dependent (115).

\section{Monocytes and Macrophages}

Macrophages are specialized in sensing and attacking invading pathogens, in modulating the immune response by secretion of inflammatory mediators and finally in contributing to healing of damaged tissues (125). Given that macrophages secrete A2M $(126,127)$ and also express both A2M receptors $(128-130)$ it is not surprising that protease-A2M* complexes are efficiently taken up by macrophages (131) and that several roles for $\mathrm{A} 2 \mathrm{M}^{\star}$ in macrophage function have been proposed (Figure 5).

Comparable to neutrophils, A2M increases the phagocytic and anti-microbial capacity of macrophages. For example, Trypanosoma cruzi, the parasite causing Chagas' disease, undergoes more efficient uptake by mouse macrophages when pre-treated with A2M (132). Human monocyte-derived macrophages pre-treated with activated A2M or A2M-enriched microparticles or microcapsules also increase bacterial phagocytosis (E. coli), phagocytosis of zymosan and ROS production $(115,117)$. This effect can be blocked by anti-LRP1 antibodies and is thus thought to be mediated through LRP-1 (115). Interestingly, several lines of research support the idea that the activation of anti-bacterial or antiviral pathways in macrophages leads to the suppression of A2M function and its associated pathways. For example, endotoxin stimulation suppresses A2M secretion, and stimulation with LPS or interferon (IFN) $\boldsymbol{\gamma}$ results in a reduced mRNA expression of LRP-1 (128, 133). In the macrophage-derived cell line J774, effects triggered by $\mathrm{A}_{2} \mathrm{M}^{* *}$ and occurring though LRP-1, could also be abrogated when cells were first challenged with LPS (134). Even microglia, the resident macrophages of the central nervous system, express LRP-1 and internalize A2 $\mathrm{M}^{\star *}$, a process which is decreased upon stimulation with LPS or IFN- $\gamma$ (135).

In a series of studies on mouse macrophages, Misra et al. performed a detailed analysis of the cell signaling cascades activated by $\mathrm{A} 2 \mathrm{M}^{*} / \mathrm{A} 2 \mathrm{M}^{* *}$ and mediated through GRP78. When stimulated with $\mathrm{A}_{2} \mathrm{M}^{* *}$, mouse macrophages undergo a rapid increase in intracellular $\mathrm{Ca}^{2+}$ and in signaling molecules such as inositol trisphosphate (IP3), diacyl glycerol (DAG), arachidonic acid (AA), lysophosphatidylcholine (lysoPC) and cyclic adenosine monophosphate (cAMP) $(14,136)$. In addition, a gradual increase in cytosolic $\mathrm{pH}$ occurs (130). Several pathways were identified including phosphorylation of phospholipase $\mathrm{C} \gamma 1$ (PLC $\gamma 1)$ and an increase in phosphorylation, activity and membrane/nuclear translocation of cytosolic phospholipase A2 (cPLA2) $(130,137,138)$. Activation of several mitogen-activated protein kinase (MAPK) cascades was also suggested based on the finding of increased phosphorylation of MEK 1/2, ERK 1/2, p38 MAPK, and JNK (137). Phosphorylation of the transcription factor cAMP response element-binding (CREB) protein was also reported (139). Activation of these pathways may have several important consequences for macrophage biology. For example, increased protein and DNA synthesis was reported, which improved cell division $(139,140)$. Synthesis and metabolism of platelet activating factor (PAF) was altered, resulting in increased release of this potent inducer of acute inflammation (141). Typsin- $\mathrm{A}_{2} \mathrm{M}^{\star}$ and $\mathrm{A} 2 \mathrm{M}^{\star *}$ could also induce the secretion of eicosanoids [e.g. prostaglandin E2 (PGE2)] from cultured mouse macrophages $(142,143)$. This occurs through upregulation of total cellular and nuclear cyclooxygenase-2 [COX2, also known as prostaglandin-endoperoxide synthase-2 (PTGS2)], and requires participation of both the p21-ras dependent MAPK 


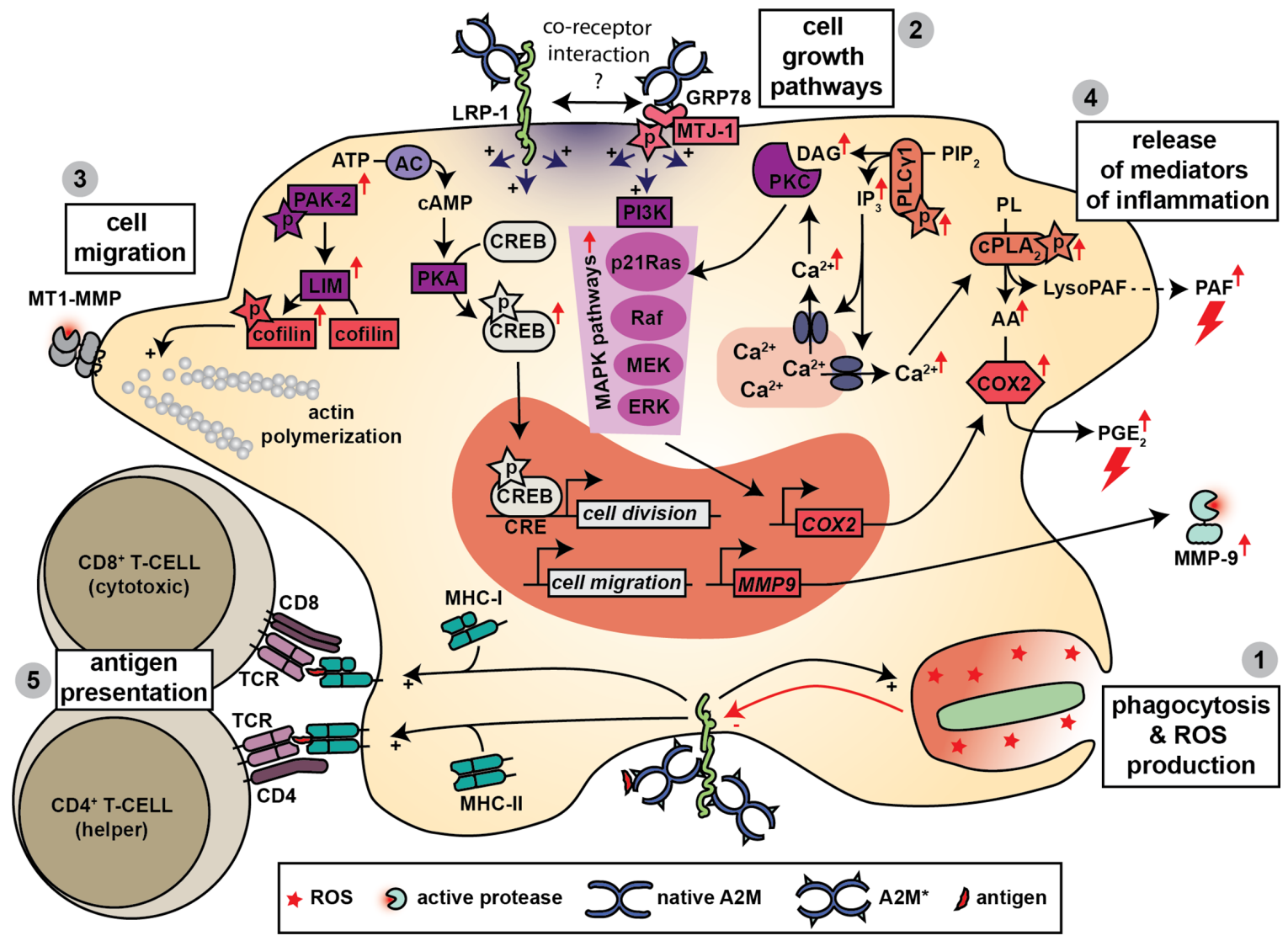

FIGURE 5 | A2M and macrophage function. Macrophages produce A2M and express both A2M receptors. Hence, several functions for A2M have been proposed in macrophage biology. A2M promotes bacterial phagocytosis, killing and the production of ROS (1) and this effect might be mediated through interaction with LRP1. Triggering of LRP-1 and/or GRP78-associated signaling pathways leads to several cellular effects. A first effect is increased cell growth, which is mediated through activation of MAPK pathways, phosphorylation of CAMP response element-binding (CREB) protein and activation of protein kinase C (PKC) (2). A second effect is increased cell migration, which might occur through increased phosphorylation of cofilin, activation of actin polymerization and the formation of enlarged cellular protrusions containing MT1-MMP (3). Binding to LRP-1 and/or GRP78 also results in a rapid increase in intracellular calcium which is thought to contribute to the release of mediators of inflammation including platelet activating factor (PAF), prostaglandin E2 (PGE2) and matrix metalloproteinase-9 (MMP-9) (4). Finally, A2M also promotes antigen presentation by macrophages where both MHC-I and MHC-II presentation have been reported (5).

and PI 3-kinase signaling pathways (144). Finally, given the fact that these pathways were resistant to inhibition by the LRP-1 antagonist RAP, it was suggested that these are triggered mainly through the GRP78 receptor $(12,92,130)$. In addition, silencing of LRP-1 did not have an effect on A2M ${ }^{\star *}$-induced IP3 synthesis (13). Nevertheless, based on the co-immunoprecipitation of GRP78 with LRP-1 a co-receptor relationship was also suggested (13). In a different study increased cell proliferation by $\mathrm{A}^{2} \mathrm{M}^{\star *}$ (in the J774 macrophage-derived cell line) also relied on MAP kinase phosphorylation (Mek1-ERK1/2 pathway), but was dependent on LRP-1 (134). Furthermore, in a follow-up study it was shown that $\mathrm{A}_{2} \mathrm{M}^{* *}$ also induces the expression and secretion of MMP-9 and involved PKC and extracellular calcium influxes (145).

A2M can also influence macrophage morphology and their capacity to migrate. For example, $\mathrm{A} 2 \mathrm{M}^{\star} / \mathrm{A} 2 \mathrm{M}^{* *}$ are able to counter IFN- $\gamma$-induced morphological changes in mouse peritoneal macrophages (146). Furthermore, in a macrophage- derived cell line (Raw264.7 cells), A2M** increased cell migration in an in vitro wound-migration assays, and induced the formation of enlarged cellular protrusions containing MT1-MMP. This process was dependent on LRP-1 and was mediated through activation of PKC (147). In contrast, in a study by Misra et al., mouse macrophages stimulated with $\mathrm{A}_{2} \mathrm{M}^{* *}$ had increased tyrosine phosphorylation of GRP78, autophosphorylation of p21-activated protein kinase-2 (PAK-2), phosphorylation of LIM kinase and cofilin, causing cytoskeletal rearrangements (148).

Finally, a role for A2M in promoting antigen presentation by macrophages was suggested. Antigens conjugated to A2M are efficiently taken up by mouse macrophages which results in efficient activation of murine T-cells, which suggests that A2M could aid in antigen presentation (149). For example, hen egg lysozyme (HEL), complexed to elastase-A2M* (ELA-A2M*HEL), is taken up by mouse macrophages more efficiently than free HEL, a process which relies on receptor-mediated endocytosis. Subsequently, the threshold for antigen 
presentation to (and activation of) HEL-specific T-hydridoma cells was 2.2 to $2.7 \log$ units lower than free HEL (15). In rabbits, subcutaneous injection of ELA-A2M*-HEL complexes also resulted in 10 to 500 -fold higher IgG titers compared to uncomplexed controls (150). Furthermore, this adjuvant-like effect could also be established with microbial antigens. Proteins isolated from Kirsten murine sarcoma virus and subsequently conjugated to A2M (by activation with trypsin), were more efficiently taken up by mouse thioglycolate-induced peritoneal exudate cells compared to unconjugated viral proteins. Subsequent co-culturing with spleen cells resulted in higher amounts of antibodies against viral proteins (151). Similarly, complexes between cruzipain, a cysteine protease from Trypanosoma cruzi, and $\mathrm{A}_{2} \mathrm{M}^{\star}$ were more efficiently taken up by human monocytes and resulted in enhanced (MHC-II-dependent) presentation of cruzipain peptides to CD4+ T cells from patients witch Chagas' disease (152).

A new insight in A2M-mediated antigen presentation was achieved with the identification of LRP-1 as the receptor for the heat shock protein gp96/CD91 (153). Gp96 is known for its immunogenicity through antigen binding, followed by uptake and MHC-I dependent presentation by antigen presenting cells. Given the striking similarities with $\mathrm{A} 2 \mathrm{M}$, the same research group subsequently confirmed that both gp96 and A2M act as Tcell adjuvants that can facilitate the transition of exogenous antigens into the endogenous pathway for antigen presentation (154). This effect was corroborated in a study where an $\mathrm{A}_{2} \mathrm{M}^{\star *}$ delivered antigen enhanced the expansion of a CD8+ $\mathrm{T}$ cell population, resulting in a 25 -fold greater secretion of IFN- $\gamma$ and IL-2, and induced cell-mediated cytotoxicity (16). Hence, both MHC-I and MHC-II-dependent processes can be promoted by antigen conjugation to A2M.

\section{Lymphocytes}

As discussed previously, binding to activated A2M increases the ability of antigens to be presented to T-cells by macrophages and this can happen both in MHC-I and MHC-II context $(16,149-$ $152,154)$. Hence, A2M can have an indirect effect on lymphocyte proliferation. In addition, A2M can bind several cytokines, including IL-2 which is a produced by activated T-cells. Due to its small size, the cytokine IL- 2 can still be degraded by A2M ${ }^{*}$ captured trypsin, resulting in the loss of its capacity to stimulate the proliferation of mouse cytotoxic $\mathrm{T}$ lymphocytes (CTLL-20 cells) and primary human lymphocytes $(155,156)$. A2M can capture proteases ranging from approximately 20 to $100 \mathrm{kDa}$ and allows substrates of up to approximately $17 \mathrm{kDa}$ to enter its molecular cage (depending on their overall structure) (4). Hence, the proteolytic activity of A2M-bound proteases remains highly relevant in the context of immune-modulation by small soluble cytokines. Given the important role for cytokines such IL-2 in lymphocyte function, one might wonder what the net contribution of $\mathrm{A} 2 \mathrm{M}$ is taking the potential proteolysis and degradation of cytokines into account. Furthermore, A2M might switch proteolysis to smaller substrates while inhibition of large or cell surface-bound substrates remains intact. To that regard, Petersen et al., reported that native A2M blocks T-cell- mediated cytotoxicity and that this effect relies on the antiproteolytic activities of A2M (157). Direct effects of A2M on lymphocyte biology have, however, not yet been described. Perhaps this is due to the fact that the expression of the LRP-1 receptor in T-cells and B-cells is limited, albeit, recent RNA-Seq studies profiling human PMBC immune subsets demonstrated an expression level of LRP-1 similar (or even higher than) neutrophils in certain T-cell and B-cell subsets $(87,158)$.

\section{A2M IN INFLAMMATION AND INFECTION}

In this part we discuss the established relevance of $\mathrm{A} 2 \mathrm{M}$ in a selection of immune-mediated pathologies and its contribution to infections. Most disease-related studies focus on the ability of $\mathrm{A} 2 \mathrm{M}$ to inactivate active proteases and its ability to bind cytokines, whereas other contributions of $\mathrm{A} 2 \mathrm{M}$ remain unexplored.

\section{A2M in Sepsis Syndromes}

In patients with sepsis or animal models for sepsis, plasma native $\mathrm{A} 2 \mathrm{M}$ is decreased whereas activated $\mathrm{A} 2 \mathrm{M}$ is present at higher levels. This change is likely due to the formation of complexes with proteases released by activated neutrophils or proteases that are part of the fibrinolytic or coagulation cascade. Hence, complexes such as plasmin-A2 $\mathrm{M}^{\star}$, thrombin-A2 $\mathrm{M}^{\star}$, cathepsinG-A2M ${ }^{\star}$, and elastase-A2M ${ }^{\star}$ can be found $(159,160)$. In guineapigs, depletion of $\mathrm{A} 2 \mathrm{M}$ results in high lethality upon administration of pseudomonal elastase or Pseudomonas aeruginosa culture supernatants, an effect that appears to rely on activation of coagulation factor XII (also known as Hageman factor), which is a serine endopeptidase part of the coagulation cascade. Furthermore, restoration of A2M levels could abrogate this effect (161). In a different study, A2M-deficient mice were also more sensitive to endotoxin, but induction of a lethal Gramnegative infection with Klebsiella pneumoniae rendered A2Mdeficient mice more resistant. A2M-deficient mice more efficiently cleared $K$. pneumoniae from major organs in comparison with control mice (162). This finding is highly surprising given that fact that $\mathrm{A} 2 \mathrm{M}$ promotes phagocytosis and killing of bacteria by neutrophils and macrophages.

Microparticles enriched with A2M (as produced by adherent neutrophils) are found in plasma samples from patients suffering from severe sepsis and vary according to the source of infection $(116,163)$. A2M-containing microvesicles are associated with survival in community acquired pneumonia-associated sepsis, but not with sepsis caused by fecal peritonitis (163). Furthermore, the amount of A2M-containing microparticles in plasma from sepsis survivors is higher than in plasma from nonsurvivors and healthy volunteers (116). In the CLP mouse model for bacterial sepsis, administration of soluble A2M or A2Menriched human microvesicles (A2M-E-MV) improves survival rates. A2M-E-MV also protects against hypothermia and reduces bacterial loads by improving bacterial phagocytosis. Surprisingly, both A2M and A2M-E-MV reduce total proinflammatory lipid mediator levels (e.g. PGE2), increase IFN- $\gamma$ levels, and A2M-E$\mathrm{MV}$ alone increase pro-resolving lipid mediator levels. 
Furthermore, mice receiving A2M-E-MV had lower levels of peritoneal leukocytes and lung myeloperoxidase levels (115). Finally, a conjugate between the LPS-binding antibiotic Polymyxin B and A2M was also able to decrease the lethality of both LPS-induced acute inflammation and polymicrobial sepsis induced by cecal ligation and puncture (CLP) in mice, when administered before or shortly after start of the model (164). Overall, it appears that supplementation with A2M or A2M-microparticles, has beneficial outcomes in sepsis and might have therapeutic potential in these syndromes.

\section{Lung Inflammation}

Lung inflammation is characterized by abundant secretion of extracellular proteases which contribute to lung damage (165). A logical role for $\mathrm{A} 2 \mathrm{M}$ is therefore the inhibition of excessive proteolysis. Indeed, during acute respiratory distress syndrome (ARDS), A2M binds active NE. However, whereas A2Mcaptured NE is no longer able to cleave insoluble elastin, it remains active against small substrates and this activity can no longer be inhibited by alpha-1-antitrypsin (104). NE captured by A2M might therefore no longer contribute to connective tissue injury, but is still able to modify smaller substrates such as cytokines. This again supports the hypothesis that A2M switches proteolysis towards the catalysis of small substrates. Another particularly interesting discovery is the finding of complexes between IL- 8 and activated A2M in lung fluids from patients with ARDS. Whereas these complexes might not be detectible by standard IL-8 immunoassays, IL-8 complexed to A2M retains its ability to attract and activate neutrophils and even protects IL-8 against proteolysis by $\mathrm{NE}(48,166)$. As a result, the complexes might account for an underestimation of biologically active IL- 8 .

\section{Rheumatic Diseases}

In the inflamed joint, $\mathrm{A} 2 \mathrm{M}$ is associated with synovial fluid monocytes, cells of the synovial lining and perivascular cells. Furthermore, the abundancy of A2M correlates with the degree of inflammation (167-169). Levels of inactive A2M correlate with neutrophil numbers and are thought to be generated by intraarticular reaction with proteases or by oxidating agents. Whereas $\mathrm{A} 2 \mathrm{M}$ is found complexed to elastase-like and chymotrypsin-like proteases (presumably NE and cathepsin G), the majority of inactive $\mathrm{A} 2 \mathrm{M}$ is thought to be generated through reaction with ROS (170). A first consequence of A2M oxidation is the decreased capacity of oxidized A2M to inhibit proteases. Synovial fluids from patients with rheumatoid arthritis (RA) contain a 2-fold higher amount of A2M compared to that from osteoarthritis (OA) patients, but the amount of oxidized A2M in $\mathrm{RA}$ is significantly higher and the ability of A2M to inhibit proteolysis is lower than that with OA (111). A2M oxidation also influences the capacity of A2M to bind cytokines and growth factors. It has also been proposed that A2M oxidation downregulates inflammation by shifting the A2M cytokine/growth factor binding profile towards TNF- $\alpha$, IL-2, and IL-6, while upregulating the development of tissue repair by reduced binding to bFGF, $\beta$-NGF, PDGF, and TGF- $\beta$. To that regards, it was shown that A2M from synovial fluid of RA patients, had a decreased capacity to bind TGF- $\beta$ compared to A2M from synovial fluid of
OA patients (46). Finally, hypochlorite-induced oxidation of $\mathrm{A} 2 \mathrm{M}$ also induces the chaperone function of A2M. It remains to be determined what the contribution of this effect would be in arthritis.

Another finding is that NE-A2M* complexes can still degrade proteoglycan in sections of human articular cartilage (171). Furthermore, injection of collagenase- $\mathrm{A}_{2} \mathrm{M}^{\star}$ or trypsin- $\mathrm{A}_{2} \mathrm{M}^{\star}$ complexes into the joint cavity of healthy rabbits, also causes experimental synovitis which is more severe than trypsin or collagenase alone (167). Nevertheless, administration of A2M appears to have merit. In rats undergoing anterior cruciate ligament transection, intra-articular injection of $\mathrm{A} 2 \mathrm{M}$ or $\mathrm{A} 2 \mathrm{M}$ variants (with altered bait regions) attenuates OA damage, presumably by inhibiting cartilage degrading enzymes (172). In a collagen II-induced arthritis model in mice, injection of A2M into the ankles, significantly reduced ankle thickness and improved disease scores (173). Finally, miR-146b, a microRNA associated with $\mathrm{OA}$, was shown to negatively regulate $\mathrm{A} 2 \mathrm{M}$ again supporting an overall beneficial role for A2M in arthritis (174).

\section{Infections}

Given the unique mechanism and the broad substrate/inhibition repertoire of $\mathrm{A} 2 \mathrm{M}$, it is no surprise that it also binds proteases from microbial origin such as Vibrio vulnificus derived metalloprotease (175) and Trypanosoma cruzi cruzipain (176, 177). Cruzipain is the main cysteine protease present in all lifecycle stages of T. cruzi and in the presence of A2M, T. cruzi is more efficiently taken up by mouse macrophages (132). Furthermore, A2M also reduces T. cruzi-induced apoptosis of host cells and $\mathrm{A}_{2} \mathrm{M}^{* *}$ reduces DNA fragmentation of infected mouse macrophages (178). Finally, mice surviving T. cruziinfection have higher levels of $\mathrm{A} 2 \mathrm{M}$ compared to nonsurviving mice (179). Whereas mice deficient in A2Ms have a lower blood parasitemia, analysis of mouse hearts revealed more amastigote nests and inflammatory infiltrates (180). Altogether, this suggests a protective role for $\mathrm{A} 2 \mathrm{M}$ in T. cruzi infection.

$\mathrm{A} 2 \mathrm{M}$ can also directly bind to pathogens and thereby influence the course of infections. A2M binds to the cell wall of Streptococci through binding of protein GRAB, a cell surface protein discovered on Streptococcus pyogenes and several clinical isolates. Surprisingly, A2M bound to $S$. pyogenes GRAB remains capable of inhibiting microbial and host proteases. Given that $S$. pyogenes mutants lacking GRAB have reduced virulence, it is hypothesized that $S$. pyogenes uses $\mathrm{A} 2 \mathrm{M}$ as a protecting factor against host proteases $(123,181)$. This hypothesis was confirmed by the discovery that SpeB, a cysteine protease secreted by $S$. pyogenes, binds GRAB-bound $\mathrm{A} 2 \mathrm{M}$ and protects these bacteria against the host antibacterial peptide LL-37 (182).

A role for $\mathrm{A} 2 \mathrm{M}$ in the innate immune defense against viruses has also been proposed. In a proteomics study to identify the components of saliva responsible for inhibition of the $\mathrm{H} 1 \mathrm{~N} 1$ swine origin influenza A virus (virus-induced erythrocyte hemagglutination assay), A2M was identified as an essential inhibitor. The proposed mechanism involves the inhibition of host proteases responsible for influenza virus hemagglutinin activation and competition with the virus for binding 2,6sialylated glycoprotein receptors on the host (183). Recently, it 
was also hypothesized that $\mathrm{A} 2 \mathrm{M}$ might confer some protection from COVID-19 through its ability to protect the vascular endothelium and potential antithrombin activity. In addition, children have considerably higher plasma levels of A2M, which might correspond to the fact that children remain relatively resistant to severe COVID-19 $(184,185)$. However, the analysis of $\mathrm{A} 2 \mathrm{M}$ protein levels in plasma samples from patients with COVID-19 revealed no significant differences or correlations with other disease parameters (186).

\section{DISCUSSION}

$\mathrm{A} 2 \mathrm{M}$ is a unique macromolecule that interacts with a broad range of endopeptidases. Based on this feature and its ability to inhibit these proteases, its potential biological relevance is enormous. During inflammation, A2M protects against structural damage by inhibition of proteases released by activated leukocytes (e.g. neutrophils) (172). At the same time, A $2 \mathrm{M}$ also inhibits proteases secreted by invading microorganisms (161). While A2M is mainly known as a general protease inhibitor, the discovery of many exceptions to this principle has indicated that $\mathrm{A} 2 \mathrm{M}$ function is far more sophisticated than just protease inhibition. The mechanism through which A2M imposes protease inhibition provides the first clue for other important functions of A2M. A2M inhibits active proteases by forming a molecular cage around the protease and shielding the protease from its substrates (Figure 1) (2). However, this also implies that small proteins with the ability to access the A2M cage can still be subject to proteolysis (3). At the same time, the A2M cage also protects proteases from further inhibition by other protease inhibitors. For example, NE captured by $\mathrm{A} 2 \mathrm{M}$ is no longer able to cleave insoluble elastin but remains active against small substrates. In addition, this activity can no longer be inhibited by alpha-1-antitrypsin (104). Whereas this finding is particularly important for conditions involving lung inflammation, similar effects can be anticipated in other conditions where major effects relate to the activity of small proteins. As an example, inflammatory chemokines are very susceptible to proteolysis and this modification can inactivate or even increase chemokine activity (187). Hence, it remains to be determined what the contribution of $\mathrm{A} 2 \mathrm{M}$ could be in processes relying on chemokine activity. Along the same line, A2M (in particular $\mathrm{A}_{2} \mathrm{M}^{\star}$ ) can bind to several cytokines and growth factors. Whereas this interaction seems to have no influence on IFN- $\gamma$, IL- $1 \beta$, IL- 8 and IL- 6 activities, binding to FGF2, PDGF, TGF- $\beta 1$ and TGF- $\beta 2$ results in functional inhibition (see Table 1). Furthermore, for IL-6 and IL-8, A2M was shown to protect against proteolytic inactivation $(47,48)$. For many other cytokines and growth factors the functional relevance of this interaction remains to be determined. In addition, oxidative modification of $\mathrm{A} 2 \mathrm{M}$ also alters the cytokine/growth factor binding capacity of A2M, presumably lowering proinflammatory mediators and aiding tissue healing (46).

In in vitro assays, A2M contributes to phagocytosis and killing of bacteria by neutrophils and macrophages. In both cell types, A2M increases the production of ROS or facilitates phagocytosis either indirectly through binding to the bacterium or directly through interaction with LRP-1 (115). Surprisingly, in A2M-deficient mice, K. pneumoniae was cleared more efficiently from major organs in comparison with control mice (162). Hence, the 'net' contribution of A2M in active bacterial infections in vivo remains to be determined. Furthermore, the exact contribution of A2M to pathogen clearance might also be pathogen-dependent. For example, in case of S. pyogenes, A2M functions as a virulence factor by binding to the bacterial surface and by capturing the bacterial protease SpeB and using it as protection against antibacterial peptides produced by the host (182).

Another shared contribution of $\mathrm{A} 2 \mathrm{M}$ to neutrophil and macrophage function relates to increasing their motility (Figure 4). In macrophages, $\mathrm{A}_{2} \mathrm{M}^{\star}$ mainly appears to induce chemokinesis by activation of signaling pathways associated with cytoskeletal rearrangements $(147,148)$. In neutrophils, this effect mainly relates to chemotaxis and endothelial cell adhesion by inducing or stabilizing the presence of CXCR2 and CD11b (Figure 3) (115). These functions appear to be mediated through LRP-1, GRP78 or a combination of both receptors acting in a co-receptor relationship.

One discrepancy between in vitro and in vivo functions of $\mathrm{A} 2 \mathrm{M}$ relates to the secretion of mediators of inflammation. In vitro stimulation of macrophages with $\mathrm{A} 2 \mathrm{M}^{*} / \mathrm{A} 2 \mathrm{M}^{* *}$ resulted in increased production of predominantly pro-inflammatory molecules such as PAF, PGE2 and MMP-9 (141-143, 145). However, in a mouse model for sepsis, administration of A2M reduced total proinflammatory lipid mediator levels (e.g. PGE2) (115). Hence, further investigation seems necessary. Administration of $\mathrm{A} 2 \mathrm{M}$, in particular $\mathrm{A} 2 \mathrm{M}$-enriched microparticles, appears to be beneficial in models for sepsis and increased levels of $\mathrm{A} 2 \mathrm{M}$ are associate with better outcomes for sepsis patients. Hence a therapeutic use for A2M in sepsis syndromes or other types of systemic inflammations was suggested (188). Another potential application for A2M relates to its ability to enhance antigen presentation by macrophages. Antigens bound to $\mathrm{A}_{2} \mathrm{M}^{*}$ are more efficiently presented to Tcells by macrophages. Meanwhile, a technique for the rapid and efficient incorporation of non-proteolytic antigens into A2M was developed (tradename, SynerVaxTM) and this technique was proposed as a novel adjuvant technology for vaccine development or antibody production (189).

The recent discovery of hypochlorite-treated A2M as an extracellular chaperone is particularly interesting in the context of neutrophilic inflammations (113). Hypochlorite secreted by activated neutrophils results in oxidation of A2M and its dissociation into dimers. Whereas these dimers no longer have the capacity to capture active proteases, they are able to form stable complexes with other 'stressed' proteins generated by oxidative modification. Subsequently, A2M aids their removal through receptor-mediated endocytosis (112). These mechanism might contribute to our understanding of how disordered proteins or cell debris generated by aggressive inflammatory environments are cleared and how build-up of pathological 
protein aggregates are avoided (19). Finally, being a highly conserved protein sharing structural similarities with complement factors C3 and C4 (23), it is interesting to see how some of the functions of A2M might relate to functions of the complement system such as opsonization and complementmediated phagocytosis (190).

In conclusion, the potential contribution of $\mathrm{A} 2 \mathrm{M}$ to inflammation, immunity and infection is clear. However, more studies are needed to understand which are the major mechanisms through which $\mathrm{A} 2 \mathrm{M}$ contributes to pathology. To that regard, mechanistic studies using up-to-date technologies or applying in vivo models with cell specific deletion of A2M might provide crucial new insights and lead to new applications for $\mathrm{A} 2 \mathrm{M}$ or new A2M-derivatives.

\section{REFERENCES}

1. Armstrong PB, Quigley JP. Alpha2-Macroglobulin: An Evolutionarily Conserved Arm of the Innate Immune System. Dev Comp Immunol (1999) 23:375-90. doi: 10.1016/s0145-305x(99)00018-x

2. Marrero A, Duquerroy S, Trapani S, Goulas T, Guevara T, Andersen GR, et al. The Crystal Structure of Human Alpha2-Macroglobulin Reveals a Unique Molecular Cage. Angew Chem Int Ed Engl (2012) 51:3340-4. doi: 10.1002/anie. 201108015

3. Nagasawa S, Han BH, Sugihara H, Suzuki T. Studies on Alpha 2Macroglobulin in Bovine Plasma. II. Interaction of Alpha-2Macroglobulin and Trypsin. J Biochem (1970) 67:821-32. doi: 10.1093/ oxfordjournals.jbchem.a129314

4. Barrett AJ, Starkey PM. The Interaction of Alpha 2-Macroglobulin With Proteinases. Characteristics and Specificity of the Reaction, and a Hypothesis Concerning its Molecular Mechanism. Biochem J (1973) 133:709-24. doi: 10.1042/bj1330709

5. Sottrup-Jensen L. Alpha-Macroglobulins: Structure, Shape, and Mechanism of Proteinase Complex Formation. J Biol Chem (1989) 264:11539-42. doi: 10.1016/S0021-9258(18)80094-1

6. Sottrup-Jensen L, Lønblad PB, Stepanik TM, Petersen TE, Magnusson S, Jörnvall H. Primary Structure of the 'Bait' Region for Proteinases in $\alpha 2$ Macroglobulin. Nature of the Complex. FEBS Lett (1981) 127:167-73. doi: 10.1016/0014-5793(81)80197-4

7. Salvesen GS, Barrett AJ. Covalent Binding of Proteinases in Their Reaction With Alpha-2-Macroglobulin. Biochem J (1980) 187:695-701. doi: 10.1042/ bj 1870695

8. Goulas T, Garcia-Ferrer I, Marrero A, Marino-Puertas L, Duquerroy S, Gomis-Rüth FX. Structural and Functional Insight Into Pan-Endopeptidase Inhibition by $\alpha 2$-Macroglobulins. Biol Chem (2017) 398:975-94. doi: 10.1515/hsz-2016-0329

9. Gonias SL, Reynolds JA, Pizzo SV. Physical Properties of Human Alpha 2Macroglobulin Following Reaction With Methylamine and Trypsin. Biochim Biophys Acta (1982) 705:306-14. doi: 10.1016/0167-4838(82) 90252-7

10. Kristensen T, Moestrup SK, Gliemann J, Bendtsen L, Sand O, Sottrup-Jensen L. Evidence That the Newly Cloned Low-Density-Lipoprotein Receptor Related Protein (LRP) is the Alpha 2-Macroglobulin Receptor. FEBS Lett (1990) 276:151-5. doi: 10.1016/0014-5793(90)80530-v

11. Herz J, Strickland DK. LRP: A Multifunctional Scavenger and Signaling Receptor. J Clin Invest (2001) 108:779-84. doi: 10.1172/JCI13992

12. Misra UK, Chu CT, Gawdi G, Pizzo SV. Evidence for a Second Alpha-2Macroglobulin Receptor. J Biol Chem (1994) 269:12541-7. doi: 10.1016/ S0021-9258(18)99909-6

13. Misra UK, Gonzalez-Gronow M, Gawdi G, Hart JP, Johnson CE, Pizzo SV. The Role of Grp78 in Alpha-2-Macroglobulin-Induced Signal Transduction. Evidence From RNA Interference That the Low Density Lipoprotein Receptor-Related Protein is Associated With, But Not Necessary for, GRP

\section{AUTHOR CONTRIBUTIONS}

JV wrote the manuscript and YI provided crucial feedback and modifications. All authors contributed to the manuscript and approved the submitted version.

\section{FUNDING}

This research was supported by the Research Foundation Flanders/FWO-Vlaanderen (G0A3820N) and the Belgian Charcot Foundation (JV). JV is supported by a senior postdoctoral fellowship of the Research Foundation of Flanders (FWO Vlaanderen, mandate 12Z0920N).

78-Mediated Signal Transduction. J Biol Chem (2002) 277:42082-7. doi: 10.1074/jbc.M206174200

14. Misra UK, Chu CT, Rubenstein DS, Gawdi G, Pizzo SV. ReceptorRecognized Alpha-2-Macroglobulin-Methylamine Elevates Intracellular Calcium, Inositol Phosphates and Cyclic AMP in Murine Peritoneal Macrophages. Biochem J (1993) 290:885-91. doi: 10.1042/bj2900885

15. Chu CT, Pizzo SV. Receptor-Mediated Antigen Delivery Into Macrophages. Complexing Antigen to Alpha 2-Macroglobulin Enhances Presentation to T Cells. J Immunol (1993) 150:48-58.

16. Bowers EV, Horvath JJ, Bond JE, Cianciolo GJ, Pizzo SV. Antigen Delivery by Alpha(2)-Macroglobulin Enhances the Cytotoxic T Lymphocyte Response. J Leukoc Biol (2009) 86:1259-68. doi: 10.1189/jlb.1008653

17. Huang JS, Huang SS, Deuel TF. Specific Covalent Binding of PlateletDerived Growth Factor to Human Plasma Alpha 2-Macroglobulin. Proc Natl Acad Sci U S A (1984) 81:342-6. doi: 10.1073/pnas.81.2.342

18. James K. Interactions Between Cytokines and Alpha 2-Macroglobulin. Immunol Today (1990) 11:163-6. doi: 10.1016/0167-5699(90)90165-6

19. Cater JH, Wilson MR, Wyatt AR. Alpha-2-Macroglobulin, a HypochloriteRegulated Chaperone and Immune System Modulator. Oxid Med Cell Longev (2019) 2019:5410657. doi: 10.1155/2019/5410657

20. Sottrup-Jensen L, Stepanik TM, Kristensen T, Lonblad PB, Jones CM, Wierzbicki DM, et al. Common Evolutionary Origin of Alpha 2Macroglobulin and Complement Components C3 and C4. Proc Natl Acad Sci U S A (1985) 82:9-13. doi: 10.1073/pnas.82.1.9

21. Ricklin D, Reis ES, Mastellos DC, Gros P, Lambris JD. Complement Component C3 - The "Swiss Army Knife" of Innate Immunity and Host Defense. Immunol Rev (2016) 274:33-58. doi: 10.1111/imr.12500

22. Quigley JP, Armstrong PB. Invertebrate Alpha 2-Macroglobulin: StructureFunction and the Ancient Thiol Ester Bond. Ann N Y Acad Sci (1994) 712:131-45. doi: 10.1111/j.1749-6632.1994.tb33568.x

23. Shokal U, Eleftherianos I. Evolution and Function of Thioester-Containing Proteins and the Complement System in the Innate Immune Response. Front Immunol (2017) 8:759. doi: 10.3389/fimmu.2017.00759

24. Janssen BJ, Huizinga EG, Raaijmakers HC, Roos A, Daha MR, NilssonEkdahl K, et al. Structures of Complement Component C3 Provide Insights Into the Function and Evolution of Immunity. Nature (2005) 437:505-11. doi: $10.1038 /$ nature 04005

25. Garcia-Ferrer I, Marrero A, Gomis-Ruth FX, Goulas T. Alpha-2Macroglobulins: Structure and Function. Subcell Biochem (2017) 83:14983. doi: 10.1007/978-3-319-46503-6_6

26. Enghild JJ, Thogersen IB, Salvesen G, Fey GH, Figler NL, Gonias SL, et al. Alpha-Macroglobulin From Limulus Polyphemus Exhibits Proteinase Inhibitory Activity and Participates in a Hemolytic System. Biochemistry (1990) 29:10070-80. doi: 10.1021/bi00495a009

27. Armstrong PB, Melchior R, Swarnakar S, Quigley JP. Alpha-2Macroglobulin Does Not Function as a C3 Homologue in the Plasma Hemolytic System of the American Horseshoe Crab, Limulus. Mol Immunol (1998) 35:47-53. doi: 10.1016/s0161-5890(98)00007-8 
28. Salvesen GS, Sayers CA, Barrett AJ. Further Characterization of the Covalent Linking Reaction of Alpha 2-Macroglobulin. Biochem J (1981) 195:453-61. doi: 10.1042/bj1950453

29. Dodds AW, Law SK. The Phylogeny and Evolution of the Thioester BondContaining Proteins C3, C4 and Alpha 2-Macroglobulin. Immunol Rev (1998) 166:15-26. doi: 10.1111/j.1600-065x.1998.tb01249.x

30. Chu CT, Pizzo SV. Alpha 2-Macroglobulin, Complement, and Biologic Defense: Antigens, Growth Factors, Microbial Proteases, and Receptor Ligation. Lab Invest (1994) 71:792-812.

31. Terai I, Kobayashi K, Matsushita M, Fujita T, Matsuno K. Alpha 2Macroglobulin Binds to and Inhibits Mannose-Binding Protein-Associated Serine Protease. Int Immunol (1995) 7:1579-84. doi: 10.1093/intimm/7.10.1579

32. Ambrus G, Gal P, Kojima M, Szilagyi K, Balczer J, Antal J, et al. Natural Substrates and Inhibitors of Mannan-Binding Lectin-Associated Serine Protease-1 and -2: A Study on Recombinant Catalytic Fragments. J Immunol (2003) 170:1374-82. doi: 10.4049/jimmunol.170.3.1374

33. Parej K, Dobo J, Zavodszky P, Gal P. The Control of the Complement Lectin Pathway Activation Revisited: Both C1-Inhibitor and Antithrombin are Likely Physiological Inhibitors, While Alpha-2-Macroglobulin is Not. Mol Immunol (2013) 54:415-22. doi: 10.1016/j.molimm.2013.01.009

34. Storgaard P, Holm Nielsen E, Skriver E, Andersen O, Svehag SE. MannanBinding Protein Forms Complexes With Alpha-2-Macroglobulin. A Protein Model for the Interaction. Scand J Immunol (1995) 42:373-80. doi: 10.1111/ j.1365-3083.1995.tb03670.x

35. Arnold JN, Wallis R, Willis AC, Harvey DJ, Royle L, Dwek RA, et al. Interaction of Mannan Binding Lectin With Alpha-2-Macroglobulin via Exposed Oligomannose Glycans: A Conserved Feature of the Thiol Ester Protein Family? J Biol Chem (2006) 281:6955-63. doi: 10.1074/ jbc.M511432200

36. Naseraldeen N, Michelis R, Barhoum M, Chezar J, Tadmor T, Aviv A, et al. The Role of Alpha-2-Macroglobulin in IgG-Aggregation and Chronic Activation of the Complement System in Patients With Chronic Lymphocytic Leukemia. Front Immunol (2020) 11:603569. doi: 10.3389/ fimmu.2020.603569

37. McDaniel MC, Laudico R, Papermaster BW. Association of MacrophageActivation Factor From a Human Cultured Lymphoid Cell Line With Albumin and Alpha-2-Macroglobulin. Clin Immunol Immunopathol (1976) 5:91-104. doi: 10.1016/0090-1229(76)90153-7

38. Ronne H, Anundi H, Rask L, Peterson PA. Nerve Growth Factor Binds to Serum Alpha-2-Macroglobulin. Biochem Biophys Res Commun (1979) 87:330-6. doi: 10.1016/0006-291x(79)91683-8

39. Asplin IR, Wu SM, Mathew S, Bhattacharjee G, Pizzo SV. Differential Regulation of the Fibroblast Growth Factor (FGF) Family by Alpha(2)Macroglobulin: Evidence for Selective Modulation of FGF-2-Induced Angiogenesis. Blood (2001) 97:3450-7. doi: 10.1182/blood.v97.11.3450

40. Crookston KP, Webb DJ, Wolf BB, Gonias SL. Classification of Alpha-2Macroglobulin-Cytokine Interactions Based on Affinity of Noncovalent Association in Solution Under Apparent Equilibrium Conditions. J Biol Chem (1994) 269:1533-40. doi: 10.1016/S0021-9258(17)42289-7

41. Dennis PA, Saksela O, Harpel P, Rifkin DB. Alpha 2-Macroglobulin is a Binding Protein for Basic Fibroblast Growth Factor. J Biol Chem (1989) 264:7210-6. doi: 10.1016/S0021-9258(18)83222-7

42. James K, van den Haan J, Lens S, Farmer K. Preliminary Studies on the Interaction of TNF Alpha and IFN Gamma With Alpha 2-Macroglobulin. Immunol Lett (1992) 32:49-57. doi: 10.1016/0165-2478(92)90198-w

43. Borth W, Luger TA. Identification of Alpha 2-Macroglobulin as a Cytokine Binding Plasma Protein. Binding of Interleukin-1 Beta to "F" Alpha 2Macroglobulin. J Biol Chem (1989) 264:5818-25. doi: 10.1016/S0021-9258 (18) $83623-7$

44. Arandjelovic S, Dragojlovic N, Li X, Myers RR, Campana WM, Gonias SL. A Derivative of the Plasma Protease Inhibitor Alpha(2)-Macroglobulin Regulates the Response to Peripheral Nerve Injury. J Neurochem (2007) 103:694-705. doi: 10.1111/j.1471-4159.2007.04800.x

45. Borth W, Scheer B, Urbansky A, Luger TA, Sottrup-Jensen L. Binding of IL1 Beta to Alpha-Macroglobulins and Release by Thioredoxin. J Immunol (1990) 145:3747-54.

46. Wu SM, Patel DD, Pizzo SV. Oxidized Alpha2-Macroglobulin (Alpha2m) Differentially Regulates Receptor Binding by Cytokines/Growth Factors:
Implications for Tissue Injury and Repair Mechanisms in Inflammation. J Immunol (1998) 161:4356-65.

47. Matsuda T, Hirano T, Nagasawa S, Kishimoto T. Identification of Alpha 2Macroglobulin as a Carrier Protein for IL-6. J Immunol (1989) 142:148-52.

48. Kurdowska A, Carr FK, Stevens MD, Baughman RP, Martin TR. Studies on the Interaction of IL-8 With Human Plasma Alpha 2-Macroglobulin: Evidence for the Presence of IL-8 Complexed to Alpha 2-Macroglobulin in Lung Fluids of Patients With Adult Respiratory Distress Syndrome. J Immunol (1997) 158:1930-40.

49. Gonias SL, Carmichael A, Mettenburg JM, Roadcap DW, Irvin WP, Webb DJ. Identical or Overlapping Sequences in the Primary Structure of Human Alpha(2)-Macroglobulin are Responsible for the Binding of Nerve Growth Factor-Beta, Platelet-Derived Growth Factor-BB, and Transforming Growth Factor-Beta. J Biol Chem (2000) 275:5826-31. doi: 10.1074/jbc.275.8.5826

50. Bonner JC, Goodell AL, Lasky JA, Hoffman MR. Reversible Binding of Platelet-Derived Growth Factor-AA, - AB, and -BB Isoforms to a Similar Site on the "Slow" and "Fast" Conformations of Alpha 2-Macroglobulin. J Biol Chem (1992) 267:12837-44. doi: 10.1016/S0021-9258(18)42352-6

51. Webb DJ, Roadcap DW, Dhakephalkar A, Gonias SL. A 16-Amino Acid Peptide From Human Alpha2-Macroglobulin Binds Transforming Growth Factor-Beta and Platelet-Derived Growth Factor-BB. Protein Sci (2000) 9:1986-92. doi: 10.1110/ps.9.10.1986

52. Arandjelovic S, Van Sant CL, Gonias SL. Limited Mutations in Full-Length Tetrameric Human Alpha2-Macroglobulin Abrogate Binding of PlateletDerived Growth Factor-BB and Transforming Growth Factor-Beta1. J Biol Chem (2006) 281:17061-8. doi: 10.1074/jbc.M602217200

53. Raines EW, Bowen-Pope DF, Ross R. Plasma Binding Proteins for PlateletDerived Growth Factor That Inhibit its Binding to Cell-Surface Receptors. Proc Natl Acad Sci U S A (1984) 81:3424-8. doi: 10.1073/pnas.81.11.3424

54. Crookston KP, Webb DJ, Lamarre J, Gonias SL. Binding of Platelet-Derived Growth Factor-BB and Transforming Growth Factor-Beta 1 to Alpha 2Macroglobulin In Vitro and In Vivo: Comparison of Receptor-Recognized and Non-Recognized Alpha 2-Macroglobulin Conformations. Biochem J (1993) 293:443-50. doi: 10.1042/bj2930443

55. Huang SS, O'Grady P, Huang JS. Human Transforming Growth Factor Beta.Alpha 2-Macroglobulin Complex Is a Latent Form of Transforming Growth Factor Beta. J Biol Chem (1988) 263:1535-41. doi: 10.1016/S00219258(19)57337-9

56. Webb DJ, Wen J, Karns LR, Kurilla MG, Gonias SL. Localization of the Binding Site for Transforming Growth Factor-Beta in Human Alpha2Macroglobulin to a $20-\mathrm{kDa}$ Peptide That Also Contains the Bait Region. J Biol Chem (1998) 273:13339-46. doi: 10.1074/jbc.273.21.13339

57. O'Connor-McCourt MD, Wakefield LM. Latent Transforming Growth Factor-Beta in Serum. A Specific Complex With Alpha 2-Macroglobulin. J Biol Chem (1987) 262:14090-9. doi: 10.1016/S0021-9258(18)47909-4

58. LaMarre J, Hayes MA, Wollenberg GK, Hussaini I, Hall SW, Gonias SL. An Alpha 2-Macroglobulin Receptor-Dependent Mechanism for the Plasma Clearance of Transforming Growth Factor-Beta 1 in Mice. J Clin Invest (1991) 87:39-44. doi: 10.1172/JCI114998

59. Hall SW, LaMarre J, Marshall LB, Hayes MA, Gonias SL. Binding of Transforming Growth Factor-Beta 1 to Methylamine-Modified Alpha 2Macroglobulin and to Binary and Ternary Alpha 2-MacroglobulinProteinase Complexes. Biochem J (1992) 281:569-75. doi: 10.1042/ bj2810569

60. Stouffer GA, LaMarre J, Gonias SL, Owens GK. Activated Alpha 2Macroglobulin and Transforming Growth Factor-Beta 1 Induce a Synergistic Smooth Muscle Cell Proliferative Response. J Biol Chem (1993) 268:18340-4. doi: 10.1016/S0021-9258(17)46850-5

61. Wollenberg GK, LaMarre J, Rosendal S, Gonias SL, Hayes MA. Binding of Tumor Necrosis Factor Alpha to Activated Forms of Human Plasma Alpha 2 Macroglobulin. Am J Pathol (1991) 138:265-72.

62. Bhattacharjee G, Asplin IR, Wu SM, Gawdi G, Pizzo SV. The ConformationDependent Interaction of Alpha 2-Macroglobulin With Vascular Endothelial Growth Factor. A Novel Mechanism of Alpha 2Macroglobulin/Growth Factor Binding. J Biol Chem (2000) 275:26806-11. doi: $10.1074 /$ jbc.M000156200

63. Soker S, Svahn CM, Neufeld G. Vascular Endothelial Growth Factor Is Inactivated by Binding to Alpha 2-Macroglobulin and the Binding Is 
Inhibited by Heparin. J Biol Chem (1993) 268:7685-91. doi: 10.1016/S00219258(18)53011-8

64. Danielpour D, Sporn MB. Differential Inhibition of Transforming Growth Factor Beta 1 and Beta 2 Activity by Alpha 2-Macroglobulin. J Biol Chem (1990) 265:6973-7. doi: 10.1016/S0021-9258(19)39246-4

65. Philip A, O'Connor-McCourt MD. Interaction of Transforming Growth Factor-Beta 1 With Alpha 2-Macroglobulin. Role in Transforming Growth Factor-Beta 1 Clearance. J Biol Chem (1991) 266:22290-6. doi: 10.1016/ S0021-9258(18)54568-3

66. Webb DJ, Gonias SL. Chemical Modification of Alpha2-Macroglobulin to Generate Derivatives That Bind Transforming Growth Factor-Beta With Increased Affinity. FEBS Lett (1997) 410:249-53. doi: 10.1016/s0014-5793 (97)00598-x

67. Webb DJ, Gonias SL. A Modified Human Alpha 2-Macroglobulin Derivative That Binds Tumor Necrosis Factor-Alpha and Interleukin-1 Beta With High Affinity In Vitro and Reverses Lipopolysaccharide Toxicity In Vivo in Mice. Lab Invest (1998) 78:939-48.

68. Gourine AV, Gourine VN, Tesfaigzi Y, Caluwaerts N, Van Leuven F, Kluger MJ. Role of Alpha(2)-Macroglobulin in Fever and Cytokine Responses Induced by Lipopolysaccharide in Mice. Am J Physiol Regul Integr Comp Physiol (2002) 283:R218-26. doi: 10.1152/ajpregu.00746.2001

69. Herz J, Hamann U, Rogne S, Myklebost O, Gausepohl H, Stanley KK. Surface Location and High Affinity for Calcium of a 500 -Kd Liver Membrane Protein Closely Related to the LDL-Receptor Suggest a Physiological Role as Lipoprotein Receptor. EMBO J (1988) 7:4119-27. doi: 10.1002/j.1460-2075.1988.tb03306.x

70. Strickland DK, Ashcom JD, Williams S, Battey F, Behre E, McTigue K, et al. Primary Structure of Alpha 2-Macroglobulin Receptor-Associated Protein. Human Homologue of a Heymann Nephritis Antigen. J Biol Chem (1991) 266:13364-9. doi: 10.1016/S0021-9258(18)98848-4

71. Williams SE, Ashcom JD, Argraves WS, Strickland DK. A Novel Mechanism for Controlling the Activity of Alpha 2-Macroglobulin Receptor/Low Density Lipoprotein Receptor-Related Protein. Multiple Regulatory Sites for 39-kDa Receptor-Associated Protein. J Biol Chem (1992) 267:9035-40. doi: 10.1016/S0021-9258(19)50384-2

72. Daly NL, Scanlon MJ, Djordjevic JT, Kroon PA, Smith R. ThreeDimensional Structure of a Cysteine-Rich Repeat From the Low-Density Lipoprotein Receptor. Proc Natl Acad Sci U S A (1995) 92:6334-8. doi: 10.1073/pnas.92.14.6334

73. Emonard H, Theret L, Bennasroune AH, Dedieu S. Regulation of LRP-1 Expression: Make the Point. Pathol Biol (Paris) (2014) 62:84-90. doi: 10.1016/j.patbio.2014.02.002

74. Bres EE, Faissner A. Low Density Receptor-Related Protein 1 Interactions With the Extracellular Matrix: More Than Meets the Eye. Front Cell Dev Biol (2019) 7:31. doi: 10.3389/fcell.2019.00031

75. Li Y, Marzolo MP, van Kerkhof P, Strous GJ, Bu G. The YXXL Motif, But Not the Two NPXY Motifs, Serves as the Dominant Endocytosis Signal for Low Density Lipoprotein Receptor-Related Protein. J Biol Chem (2000) 275:17187-94. doi: 10.1074/jbc.M000490200

76. Willingham MC, Maxfield FR, Pastan I. Receptor-Mediated Endocytosis of Alpha 2-Macroglobulin in Cultured Fibroblasts. J Histochem Cytochem (1980) 28:818-23. doi: 10.1177/28.8.6160180

77. Holtet TL, Nielsen KL, Etzerodt M, Moestrup SK, Gliemann J, SottrupJensen L, et al. Receptor-Binding Domain of Human Alpha 2Macroglobulin. Expression, Folding and Biochemical Characterization of a High-Affinity Recombinant Derivative. FEBS Lett (1994) 344:242-6. doi: 10.1016/0014-5793(94)00349-1

78. Howard GC, Yamaguchi Y, Misra UK, Gawdi G, Nelsen A, DeCamp DL, et al. Selective Mutations in Cloned and Expressed Alpha-Macroglobulin Receptor Binding Fragment Alter Binding to Either the Alpha2Macroglobulin Signaling Receptor or the Low Density Lipoprotein Receptor-Related Protein/Alpha2-Macroglobulin Receptor. J Biol Chem (1996) 271:14105-11. doi: 10.1074/jbc.271.24.14105

79. Nielsen KL, Holtet TL, Etzerodt M, Moestrup SK, Gliemann J, SottrupJensen L, et al. Identification of Residues in Alpha-Macroglobulins Important for Binding to the Alpha2-Macroglobulin Receptor/Low Density Lipoprotein Receptor-Related Protein. J Biol Chem (1996) 271:12909-12. doi: 10.1074/jbc.271.22.12909
80. Arandjelovic S, Hall BD, Gonias SL. Mutation of Lysine 1370 in Full-Length Human Alpha2-Macroglobulin Blocks Binding to the Low Density Lipoprotein Receptor-Related Protein-1. Arch Biochem Biophys (2005) 438:29-35. doi: 10.1016/j.abb.2005.03.019

81. Moestrup SK, Gliemann J. Analysis of Ligand Recognition by the Purified Alpha 2-Macroglobulin Receptor (Low Density Lipoprotein ReceptorRelated Protein). Evidence That High Affinity of Alpha 2-MacroglobulinProteinase Complex is Achieved by Binding to Adjacent Receptors. J Biol Chem (1991) 266:14011-7. doi: 10.1016/S0021-9258(18)92803-6

82. Delain E, Barray M, Pochon F, Gliemann J, Moestrup SK. Electron Microscopic Visualization of the Human Alpha 2-Macroglobulin Receptor and its Interaction With Alpha 2-Macroglobulin/Chymotrypsin Complex. Ann N Y Acad Sci (1994) 737:202-11. doi: 10.1111/j.1749-6632.1994. tb44313.x

83. Mikhailenko I, Battey FD, Migliorini M, Ruiz JF, Argraves K, Moayeri M, et al. Recognition of Alpha 2-Macroglobulin by the Low Density Lipoprotein Receptor-Related Protein Requires the Cooperation of Two Ligand Binding Cluster Regions. J Biol Chem (2001) 276:39484-91. doi: 10.1074/ jbc.M104382200

84. Gotthardt M, Trommsdorff M, Nevitt MF, Shelton J, Richardson JA, Stockinger W, et al. Interactions of the Low Density Lipoprotein Receptor Gene Family With Cytosolic Adaptor and Scaffold Proteins Suggest Diverse Biological Functions in Cellular Communication and Signal Transduction J Biol Chem (2000) 275:25616-24. doi: 10.1074/jbc.M000955200

85. Betts GN, van der Geer P, Komives EA. Structural and Functional Consequences of Tyrosine Phosphorylation in the LRP1 Cytoplasmic Domain. J Biol Chem (2008) 283:15656-64. doi: 10.1074/jbc.M709514200

86. Mantuano E, Lam MS, Gonias SL. LRP1 Assembles Unique Co-Receptor Systems to Initiate Cell Signaling in Response to Tissue-Type Plasminogen Activator and Myelin-Associated Glycoprotein. J Biol Chem (2013) 288:34009-18. doi: 10.1074/jbc.M113.509133

87. Uhlén M, Fagerberg L, Hallström BM, Lindskog C, Oksvold P, Mardinoglu A, et al. Proteomics. Tissue-Based Map of the Human Proteome. Science (2015) 347:1260419. doi: 10.1126/science.1260419

88. Moestrup SK, Gliemann J, Pallesen G. Distribution of the Alpha 2Macroglobulin Receptor/Low Density Lipoprotein Receptor-Related Protein in Human Tissues. Cell Tissue Res (1992) 269:375-82. doi: 10.1007/BF00353892

89. Yamamoto K, Santamaria S, Botkjaer KA, Dudhia J, Troeberg L, Itoh Y, et al Inhibition of Shedding of Low-Density Lipoprotein Receptor-Related Protein 1 Reverses Cartilage Matrix Degradation in Osteoarthritis. Arthritis Rheumatol (2017) 69:1246-56. doi: 10.1002/art.40080

90. Gorovoy M, Gaultier A, Campana WM, Firestein GS, Gonias SL. Inflammatory Mediators Promote Production of Shed LRP1/CD91, Which Regulates Cell Signaling and Cytokine Expression by Macrophages. J Leukoc Biol (2010) 88:769-78. doi: 10.1189/jlb.0410220

91. Gaultier A, Arandjelovic S, Niessen S, Overton CD, Linton MF, Fazio S, et al. Regulation of Tumor Necrosis Factor Receptor-1 and the IKK-NF-kappaB Pathway by LDL Receptor-Related Protein Explains the Antiinflammatory Activity of This Receptor. Blood (2008) 111:5316-25. doi: 10.1182/blood2007-12-127613

92. Misra UK, Chu CT, Gawdi G, Pizzo SV. The Relationship Between Low Density Lipoprotein-Related Protein/Alpha 2-Macroglobulin (Alpha 2M) Receptors and the Newly Described Alpha 2M Signaling Receptor. J Biol Chem (1994) 269:18303-6. doi: 10.1016/S0021-9258(17)32305-0

93. Stolz A, Wolf DH. Endoplasmic Reticulum Associated Protein Degradation: A Chaperone Assisted Journey to Hell. Biochim Biophys Acta (2010) 1803:694-705. doi: 10.1016/j.bbamcr.2010.02.005

94. Lee AS. The Glucose-Regulated Proteins: Stress Induction and Clinical Applications. Trends Biochem Sci (2001) 26:504-10. doi: 10.1016/s09680004(01)01908-9

95. Sukata T, Uwagawa S, Ozaki K, Sumida K, Kushida M, Kakehashi A, et al. Characteristic Upregulation of Glucose-Regulated Protein 78 in an Early Lesion Negative for Hitherto Established Cytochemical Markers in Rat Hepatocarcinogenesis. J Toxicol Pathol (2009) 22:281-8. doi: 10.1293/ tox.22.281

96. Farshbaf M, Khosroushahi AY, Mojarad-Jabali S, Zarebkohan A, Valizadeh H, Walker PR. Cell Surface GRP78: An Emerging Imaging Marker and 
Therapeutic Target for Cancer. J Control Release (2020) 328:932-41. doi: 10.1016/j.jconrel.2020.10.055

97. Misra UK, Gonzalez-Gronow M, Gawdi G, Pizzo SV. The Role of MTJ-1 in Cell Surface Translocation of GRP78, a Receptor for Alpha 2Macroglobulin-Dependent Signaling. J Immunol (2005) 174:2092-7. doi: 10.4049/jimmunol.174.4.2092

98. Piette BL, Alerasool N, Lin ZY, Lacoste J, Lam MHY, Qian WW, et al. Comprehensive Interactome Profiling of the Human Hsp70 Network Highlights Functional Differentiation of J Domains. Mol Cell (2021) 81:2549-65.e8. doi: 10.1016/j.molcel.2021.04.012

99. Misra UK, Wang F, Pizzo SV. Transcription Factor TFII-I Causes Transcriptional Upregulation of GRP78 Synthesis in Prostate Cancer Cells. J Cell Biochem (2009) 106:381-9. doi: 10.1002/jcb.22016

100. Misra UK, Payne S, Pizzo SV. Ligation of Prostate Cancer Cell Surface GRP78 Activates a Proproliferative and Antiapoptotic Feedback Loop: A Role for Secreted Prostate-Specific Antigen. J Biol Chem (2011) 286:1248-59. doi: 10.1074/jbc.M110.129767

101. Salvesen G, Virca GD, Travis J. Interaction of Alpha 2-Macroglobulin With Neutrophil and Plasma Proteinases. Ann N Y Acad Sci (1983) 421:316-26. doi: 10.1111/j.1749-6632.1983.tb18120.x

102. Campbell EJ, Senior RM, McDonald JA, Cox DL. Proteolysis by Neutrophils. Relative Importance of Cell-Substrate Contact and Oxidative Inactivation of Proteinase Inhibitors In Vitro. J Clin Invest (1982) 70:845-52. doi: 10.1172/ jcil10681

103. Stone PJ, Calore JD, Franzblau C. Release of Human Neutrophil Elastase From Alpha 2-Macroglobulin Complexes Containing Human Neutrophil Elastase. Ann N Y Acad Sci (1983) 421:398-400. doi: 10.1111/j.17496632.1983.tb18132.x

104. Wewers MD, Herzyk DJ, Gadek JE. Alveolar Fluid Neutrophil Elastase Activity in the Adult Respiratory Distress Syndrome is Complexed to Alpha2-Macroglobulin. J Clin Invest (1988) 82:1260-7. doi: 10.1172/JCI113724

105. Rao NV, Wehner NG, Marshall BC, Gray WR, Gray BH, Hoidal JR. Characterization of Proteinase-3 (PR-3), a Neutrophil Serine Proteinase. Structural and Functional Properties. J Biol Chem (1991) 266:9540-8. doi: 10.1016/S0021-9258(18)92854-1

106. Nagase H, Itoh Y, Binner S. Interaction of Alpha 2-Macroglobulin With Matrix Metalloproteinases and its Use for Identification of Their Active Forms. Ann N Y Acad Sci (1994) 732:294-302. doi: 10.1111/j.17496632.1994.tb24744.x

107. Serifova X, Ugarte-Berzal E, Opdenakker G, Vandooren J. Homotrimeric MMP-9 is an Active Hitchhiker on Alpha-2-Macroglobulin Partially Escaping Protease Inhibition and Internalization Through LRP-1. Cell Mol Life Sci (2019) 77:3013-26. doi: 10.1007/s00018-019-03338-4

108. Reddy VY, Pizzo SV, Weiss SJ. Functional Inactivation and Structural Disruption of Human Alpha 2-Macroglobulin by Neutrophils and Eosinophils. J Biol Chem (1989) 264:13801-9. doi: 10.1016/S0021-9258(18) 80072-2

109. Siddiqui T, Zia MK, Ali SS, Ahsan $\mathrm{H}$, Khan FH. Insight Into the Interactions of Proteinase Inhibitor- Alpha-2-Macroglobulin With Hypochlorite. Int J Biol Macromol (2018) 117:401-6. doi: 10.1016/j.ijbiomac.2018.05.112

110. Reddy VY, Desorchers PE, Pizzo SV, Gonias SL, Sahakian JA, Levine RL, et al. Oxidative Dissociation of Human Alpha 2-Macroglobulin Tetramers Into Dysfunctional Dimers. J Biol Chem (1994) 269:4683-91. doi: 10.1016/ S0021-9258(17)41830-8

111. Wu SM, Pizzo SV. Alpha(2)-Macroglobulin From Rheumatoid Arthritis Synovial Fluid: Functional Analysis Defines a Role for Oxidation in Inflammation. Arch Biochem Biophys (2001) 391:119-26. doi: 10.1006/abbi.2001.2408

112. Wyatt AR, Kumita JR, Mifsud RW, Gooden CA, Wilson MR, Dobson CM. Hypochlorite-Induced Structural Modifications Enhance the Chaperone Activity of Human Alpha2-Macroglobulin. Proc Natl Acad Sci U S A (2014) 111:E2081-90. doi: 10.1073/pnas.1403379111

113. French K, Yerbury JJ, Wilson MR. Protease Activation of Alpha2Macroglobulin Modulates a Chaperone-Like Action With Broad Specificity. Biochemistry (2008) 47:1176-85. doi: 10.1021/bi701976f

114. Wyatt AR, Constantinescu P, Ecroyd H, Dobson CM, Wilson MR, Kumita JR, et al. Protease-Activated Alpha-2-Macroglobulin can Inhibit Amyloid Formation via Two Distinct Mechanisms. FEBS Lett (2013) 587:398-403. doi: 10.1016/j.febslet.2013.01.020
115. Dalli J, Norling LV, Montero-Melendez T, Federici Canova D, Lashin H, Pavlov AM, et al. Microparticle Alpha-2-Macroglobulin Enhances ProResolving Responses and Promotes Survival in Sepsis. EMBO Mol Med (2014) 6:27-42. doi: 10.1002/emmm.201303503

116. Dalli J, Montero-Melendez T, Norling LV, Yin X, Hinds C, Haskard D, et al. Heterogeneity in Neutrophil Microparticles Reveals Distinct Proteome and Functional Properties. Mol Cell Proteomics (2013) 12:2205-19. doi: 10.1074/ mcp.M113.028589

117. Federici Canova D, Pavlov AM, Norling LV, Gobbetti T, Brunelleschi S, Le Fauder P, et al. Alpha-2-Macroglobulin Loaded Microcapsules Enhance Human Leukocyte Functions and Innate Immune Response. J Control Release (2015) 217:284-92. doi: 10.1016/j.jconrel.2015.09.021

118. Czarnetzki BM, Schulz W. Role of Purified Serum Components in Polymorphonuclear Leukocyte Chemotaxis. Int Arch Allergy Appl Immunol (1980) 61:424-30. doi: 10.1159/000232470

119. Forrester JV, Wilkinson PC, Lackie JM. Effect of Modified Alpha 2macroglobulin on Leucocyte Locomotion and Chemotaxis. Immunology (1983) 50:251-9.

120. Chhatwal GS, Albohn G, Blobel H. Novel Complex Formed Between a Nonproteolytic Cell Wall Protein of Group A Streptococci and Alpha 2Macroglobulin. J Bacteriol (1987) 169:3691-5. doi: 10.1128/jb.169.8.36913695.1987

121. Sjobring U, Trojnar J, Grubb A, Akerstrom B, Bjorck L. Ig-Binding Bacterial Proteins Also Bind Proteinase Inhibitors. J Immunol (1989) 143:2948-54.

122. Muller HP, Rantamaki LK. Binding of Native Alpha 2-Macroglobulin to Human Group G Streptococci. Infect Immun (1995) 63:2833-9. doi: 10.1128/ iai.63.8.2833-2839.1995

123. Rasmussen M, Muller HP, Bjorck L. Protein GRAB of Streptococcus Pyogenes Regulates Proteolysis at the Bacterial Surface by Binding Alpha2Macroglobulin. J Biol Chem (1999) 274:15336-44. doi: 10.1074/ jbc.274.22.15336

124. Valentin-Weigand P, Traore MY, Blobel H, Chhatwal GS. Role of Alpha 2Macroglobulin in Phagocytosis of Group A and C Streptococci. FEMS Microbiol Lett (1990) 58:321-4. doi: 10.1111/j.1574-6968.1990.tb13997.x

125. He W, Heinz A, Jahn D, Hiller K. Complexity of Macrophage Metabolism in Infection. Curr Opin Biotechnol (2021) 68:231-9. doi: 10.1016/ j.copbio.2021.01.020

126. White R, Janoff A, Godfrey HP. Secretion of Alpha-2-Macroglobulin by Human Alveolar Macrophages. Lung (1980) 158:9-14. doi: 10.1007/ BF02713697

127. Munck Petersen C, Ejlersen E, Wendelboe Hansen P, Gliemann J. Binding of Alpha-2-Macroglobulin Trypsin Complex to Human Monocytes in Culture. Scand J Clin Lab Invest (1987) 47:55-61. doi: 10.3109/00365518709168870

128. LaMarre J, Wolf BB, Kittler EL, Quesenberry PJ, Gonias SL. Regulation of Macrophage Alpha 2-Macroglobulin Receptor/Low Density Lipoprotein Receptor-Related Protein by Lipopolysaccharide and Interferon-Gamma. I Clin Invest (1993) 91:1219-24. doi: 10.1172/JCI116283

129. Moestrup SK, Kaltoft K, Petersen CM, Pedersen S, Gliemann J, Christensen EI. Immunocytochemical Identification of the Human Alpha 2Macroglobulin Receptor in Monocytes and Fibroblasts: Monoclonal Antibodies Define the Receptor as a Monocyte Differentiation Antigen. Exp Cell Res (1990) 190:195-203. doi: 10.1016/0014-4827(90)90185-d

130. Misra UK, Gawdi G, Pizzo SV. Ligation of the Alpha 2-Macroglobulin Signalling Receptor on Macrophages Induces Protein Phosphorylation and an Increase in Cytosolic pH. Biochem J (1995) 309:151-8. doi: 10.1042/ bj3090151

131. Debanne MT, Bell R, Dolovich J. Uptake of Proteinase-Alpha-Macroglobulin Complexes by Macrophages. Biochim Biophys Acta (1975) 411:295-304. doi: 10.1016/0304-4165(75)90309-8

132. Araujo-Jorge TC, de Meirelles Mde N, Isaac L. Trypanosoma Cruzi: Killing and Enhanced Uptake by Resident Peritoneal Macrophages Treated With Alpha-2-Macroglobulin. Parasitol Res (1990) 76:545-52. doi: 10.1007/ BF00932558

133. Ganter U, Bauer J, Schulz-Huotari C, Gebicke-Haerter PJ, Beeser H, Gerok W. Repression of Alpha 2-Macroglobulin and Stimulation of Alpha 1Proteinase Inhibitor Synthesis in Human Mononuclear Phagocytes by Endotoxin. Eur J Biochem (1987) 169:13-20. doi: 10.1111/j.14321033.1987.tb13574.x 
134. Bonacci GR, Caceres LC, Sanchez MC, Chiabrando GA. Activated Alpha(2)Macroglobulin Induces Cell Proliferation and Mitogen-Activated Protein Kinase Activation by LRP-1 in the J774 Macrophage-Derived Cell Line. Arch Biochem Biophys (2007) 460:100-6. doi: 10.1016/j.abb.2007.01.004

135. Marzolo MP, von Bernhardi R, Bu G, Inestrosa NC. Expression of Alpha(2)Macroglobulin Receptor/Low Density Lipoprotein Receptor-Related Protein (LRP) in Rat Microglial Cells. J Neurosci Res (2000) 60:401-11. doi: 10.1002/ (SICI) 1097-4547(20000501)60:3<401::AID-JNR15>3.0.CO;2-L

136. Misra UK, Pizzo SV. Ligation of Alpha 2M Receptors With Alpha 2MMethylamine Stimulates the Activities of Phospholipase C, Phospholipase A2, and Protein Kinase C in Murine Peritoneal Macrophages. Ann N Y Acad Sci (1994) 737:486-9. doi: 10.1111/j.1749-6632.1994.tb44347.x

137. Misra UK, Pizzo SV. Regulation of Cytosolic Phospholipase A2 Activity in Macrophages Stimulated With Receptor-Recognized Forms of Alpha 2Macroglobulin: Role in Mitogenesis and Cell Proliferation. J Biol Chem (2002) 277:4069-78. doi: 10.1074/jbc.M109764200

138. Misra UK, Pizzo SV. Cytosolic Phospholipase A(2) Activity Associated With Nuclei is Not Inhibited by Arachidonyl Trifluoromethyl Ketone in Macrophages Stimulated With Receptor-Recognized Forms of Alpha(2)Macroglobulin. Arch Biochem Biophys (2000) 379:153-60. doi: 10.1006/ abbi.2000.1878

139. Misra UK, Akabani G, Pizzo SV. The Role of cAMP-Dependent Signaling in Receptor-Recognized Forms of Alpha 2-Macroglobulin-Induced Cellular Proliferation. J Biol Chem (2002) 277:36509-20. doi: 10.1074/ jbc.M203543200

140. Misra UK, Pizzo SV. Ligation of the Alpha2m Signaling Receptor With Receptor-Recognized Forms of Alpha2-Macroglobulin Initiates Protein and DNA Synthesis in Macrophages. The Effect of Intracellular Calcium. Biochim Biophys Acta (1998) 1401:121-8. doi: 10.1016/s0167-4889(97)00123-7

141. Misra UK, Pizzo SV. Ligation of the Alpha 2-Macroglobulin Signaling Receptor on Macrophages Induces Synthesis of Platelet Activating Factor. J Cell Biochem (1996) 61:39-47. doi: 10.1002/(SICI)1097-4644(19960401) 61:1\%3C39::AID-JCB6\%3E3.0.CO;2-3

142. Hoffman M, Pizzo SV, Weinberg JB. Alpha 2 Macroglobulin-Proteinase Complexes Stimulate Prostaglandin E2 Synthesis by Peritoneal Macrophages. Agents Actions (1988) 25:360-7. doi: 10.1007/BF01965043

143. Uhing RJ, Martenson CH, Rubenstein DS, Hollenbach PW, Pizzo SV. The Exposure of Murine Macrophages to Alpha 2-Macroglobulin 'Fast' Forms Results in the Rapid Secretion of Eicosanoids. Biochim Biophys Acta (1991) 1093:115-20. doi: 10.1016/0167-4889(91)90111-a

144. Misra UK, Pizzo SV. Induction of Cyclooxygenase-2 Synthesis by Ligation of the Macrophage Alpha(2)-Macroglobulin Signalling Receptor. Cell Signal (2001) 13:801-8. doi: 10.1016/s0898-6568(01)00202-9

145. Caceres LC, Bonacci GR, Sanchez MC, Chiabrando GA. Activated Alpha(2) Macroglobulin Induces Matrix Metalloproteinase 9 Expression by LowDensity Lipoprotein Receptor-Related Protein 1 Through MAPK-ERK1/2 and NF-kappaB Activation in Macrophage-Derived Cell Lines. J Cell Biochem (2010) 111:607-17. doi: 10.1002/jcb.22737

146. Roche PA, Hoffman MR, Pizzo SV. Effect of Interferon-Gamma and Human Alpha 2-Macroglobulin on Peritoneal Macrophage Morphology and Ia Antigen Expression. Biochim Biophys Acta (1990) 1051:166-73. doi: 10.1016/0167-4889(90)90189-k

147. Ferrer DG, Dato VA, Jaldin-Fincati JR, Lorenc VE, Sanchez MC, Chiabrando GA. Activated Alpha-2-Macroglobulin Induces Mesenchymal Cellular Migration of Raw264.7 Cells Through Low-Density Lipoprotein ReceptorRelated Protein 1. J Cell Biochem (2017) 118:1810-8. doi: 10.1002/jcb.25857

148. Misra UK, Sharma T, Pizzo SV. Ligation of Cell Surface-Associated GlucoseRegulated Protein 78 by Receptor-Recognized Forms of Alpha 2Macroglobulin: Activation of P21-Activated Protein Kinase-2-Dependent Signaling in Murine Peritoneal Macrophages. J Immunol (2005) 175:252533. doi: 10.4049/jimmunol.175.4.2525

149. Osada T, Noro N, Kuroda Y, Ikai A. Murine T Cell Proliferation can be Specifically Augmented by Macrophages Fed With Specific Antigen: Alpha2-Macroglobulin Conjugate. Biochem Biophys Res Commun (1987) 146:2631. doi: $10.1016 / 0006-291 \mathrm{x}(87) 90685-1$

150. Chu CT, Oury TD, Enghild JJ, Pizzo SV. Adjuvant-Free In Vivo Targeting. Antigen Delivery by Alpha 2-Macroglobulin Enhances Antibody Formation. J Immunol (1994) 152:1538-45.
151. Osada T, Noro N, Kuroda Y, Ikai A. Antibodies Against Viral Proteins can be Produced Effectively in Response to the Increased Uptake of Alpha 2Macroglobulin: Viral Protein Conjugate by Macrophages. Biochem Biophys Res Commun (1988) 150:883-9. doi: 10.1016/0006-291x(88)90475-5

152. Morrot A, Strickland DK, Higuchi Mde L, Reis M, Pedrosa R, Scharfstein J. Human T Cell Responses Against the Major Cysteine Proteinase (Cruzipain) of Trypanosoma Cruzi: Role of the Multifunctional Alpha 2-Macroglobulin Receptor in Antigen Presentation by Monocytes. Int Immunol (1997) 9:82534. doi: 10.1093/intimm/9.6.825

153. Binder RJ, Han DK, Srivastava PK. CD91: A Receptor for Heat Shock Protein Gp96. Nat Immunol (2000) 1:151-5. doi: 10.1038/77835

154. Binder RJ, Karimeddini D, Srivastava PK. Adjuvanticity of Alpha 2Macroglobulin, an Independent Ligand for the Heat Shock Protein Receptor CD91. J Immunol (2001) 166:4968-72. doi: 10.4049/ jimmunol.166.8.4968

155. Borth W, Teodorescu M. Inactivation of Human Interleukin-2 (IL-2) by Alpha 2-Macroglobulin-Trypsin Complexes. Immunology (1986) 57:367-71.

156. Heumann D, Vischer TL. Immunomodulation by Alpha 2-Macroglobulin and Alpha 2-Macroglobulin-Proteinase Complexes: The Effect on the Human T Lymphocyte Response. Eur J Immunol (1988) 18:755-60. doi: 10.1002/eji.1830180515

157. Petersen CM, Ejlersen E, Moestrup SK, Jensen PH, Sand O, Sottrup-Jensen L. Immunosuppressive Properties of Electrophoretically "Slow" and "Fast" Form Alpha 2-Macroglobulin. Effects on Cell-Mediated Cytotoxicity and (Allo-) Antigen-Induced T Cell Proliferation. J Immunol (1989) 142:629-35.

158. Monaco G, Lee B, Xu W, Mustafah S, Hwang YY, Carre C, et al. RNA-Seq Signatures Normalized by mRNA Abundance Allow Absolute Deconvolution of Human Immune Cell Types. Cell Rep (2019) 26:1627-40 e7. doi: 10.1016/j.celrep.2019.01.041

159. de Boer JP, Creasey AA, Chang A, Abbink JJ, Roem D, Eerenberg AJ, et al. Alpha-2-Macroglobulin Functions as an Inhibitor of Fibrinolytic, Clotting, and Neutrophilic Proteinases in Sepsis: Studies Using a Baboon Model. Infect Immun (1993) 61:5035-43. doi: 10.1128/iai.61.12.5035-5043.1993

160. Abbink JJ, Nuijens JH, Eerenberg AJ, Huijbregts CC, Strack van Schijndel RJ, Thijs LG, et al. Quantification of Functional and Inactivated Alpha 2Macroglobulin in Sepsis. Thromb Haemost (1991) 65:32-9. doi: 10.1055/s0038-1647450

161. Khan MM, Shibuya Y, Nakagaki T, Kambara T, Yamamoto T. Alpha-2Macroglobulin as the Major Defence in Acute Pseudomonal Septic Shock in the Guinea-Pig Model. Int J Exp Pathol (1994) 75:285-93.

162. Hochepied T, Van Leuven F, Libert C. Mice Lacking Alpha(2)Macroglobulin Show an Increased Host Defense Against Gram-Negative Bacterial Sepsis, But Are More Susceptible to Endotoxic Shock. Eur Cytokine Netw (2002) 13:86-91.

163. Lashin HMS, Nadkarni S, Oggero S, Jones HR, Knight JC, Hinds CJ, et al. Microvesicle Subsets in Sepsis Due to Community Acquired Pneumonia Compared to Faecal Peritonitis. Shock (2018) 49:393-401. doi: 10.1097/ SHK.0000000000000989

164. Birkenmeier G, Nicklisch S, Pockelt C, Mossie A, Steger V, Glaser C, et al. Polymyxin B-Conjugated Alpha 2-Macroglobulin as an Adjunctive Therapy to Sepsis: Modes of Action and Impact on Lethality. J Pharmacol Exp Ther (2006) 318:762-71. doi: 10.1124/jpet.106.104265

165. Shapiro SD. Proteolysis in the Lung. Eur Respir J Suppl (2003) 44:30s-2s. doi: 10.1183/09031936.03.00000903a

166. Kurdowska AK, Geiser TK, Alden SM, Dziadek BR, Noble JM, Nuckton TJ, et al. Activity of Pulmonary Edema Fluid Interleukin-8 Bound to Alpha(2)Macroglobulin in Patients With Acute Lung Injury. Am J Physiol Lung Cell Mol Physiol (2002) 282:L1092-8. doi: 10.1152/ajplung.00378.2001

167. Flory E, Vischer TL. Alpha 2-Macroglobulin as an Inclusion in Synovial Fluid Monocytes. Rheumatol Int (1981) 1(2):61-4. doi: 10.1007/BF00541154

168. Ekerot L, Ohlsson K. Immunoreactive Alpha 2-Macroglobulin in Rheumatoid Synovial Membrane. Scand J Plast Reconstr Surg (1982) 16:293-4. doi: 10.3109/02844318209026222

169. Flory ED, Clarris BJ, Muirden KD. Deposits of Alpha 2M in the Rheumatoid Synovial Membrane. Ann Rheum Dis (1982) 41:520-6. doi: 10.1136/ ard.41.5.520

170. Abbink JJ, Kamp AM, Nieuwenhuys EJ, Nuijens JH, Swaak AJ, Hack CE. Predominant Role of Neutrophils in the Inactivation of Alpha 2- 
Macroglobulin in Arthritic Joints. Arthritis Rheum (1991) 34:1139-50. doi: 10.1002/art.1780340910

171. Moore AR, Appelboam A, Kawabata K, Da Silva JA, D'Cruz D, Gowland G, et al. Destruction of Articular Cartilage by Alpha 2 Macroglobulin Elastase Complexes: Role in Rheumatoid Arthritis. Ann Rheum Dis (1999) 58:109-13. doi: 10.1136/ard.58.2.109

172. Zhang Y, Wei X, Browning S, Scuderi G, Hanna LS, Wei L. Targeted Designed Variants of Alpha-2-Macroglobulin (A2M) Attenuate Cartilage Degeneration in a Rat Model of Osteoarthritis Induced by Anterior Cruciate Ligament Transection. Arthritis Res Ther (2017) 19:175. doi: 10.1186/ s13075-017-1363-4

173. Li S, Xiang C, Wei X, Sun X, Li R, Li P, et al. Early Supplemental Alpha2Macroglobulin Attenuates Cartilage and Bone Damage by Inhibiting Inflammation in Collagen II-Induced Arthritis Model. Int J Rheum Dis (2019) 22:654-65. doi: 10.1111/1756-185X.13457

174. Liu X, Liu L, Zhang H, Shao Y, Chen Z, Feng X, et al. MiR-146b Accelerates Osteoarthritis Progression by Targeting Alpha-2-Macroglobulin. Aging (Albany NY) (2019) 11:6014-28. doi: 10.18632/aging.102160

175. Miyoshi S, Shinoda S. Inhibitory Effect of Alpha 2-Macroglobulin on Vibrio Vulnificus Protease. J Biochem (1989) 106:299-303. doi: 10.1093/ oxfordjournals.jbchem.a122848

176. Coutinho CM, Cavalcanti GH, van Leuven F, Araujo-Jorge TC. Alpha-2Macroglobulin Binds to the Surface of Trypanosoma Cruzi. Parasitol Res (1997) 83:144-50. doi: 10.1007/s004360050224

177. Ramos AM, Duschak VG, Gerez de Burgos NM, Barboza M, Remedi MS, Vides MA, et al. Trypanosoma Cruzi: Cruzipain and Membrane-Bound Cysteine Proteinase Isoform(s) Interacts With Human Alpha(2)Macroglobulin and Pregnancy Zone Protein. Exp Parasitol (2002) 100:121-30. doi: 10.1016/S0014-4894(02)00007-3

178. De Souza EM, Meuser-Batista M, Batista DG, Duarte BB, Araujo-Jorge TC, Soeiro MN. Trypanosoma Cruzi: Alpha-2-Macroglobulin Regulates Host Cell Apoptosis Induced by the Parasite Infection In Vitro. Exp Parasitol (2008) 118:331-7. doi: 10.1016/j.exppara.2007.09.004

179. Araujo-Jorge TC, Lage MJ, Rivera MT, Carlier Y, Van Leuven F. Trypanosoma Cruzi: Enhanced Alpha-Macroglobulin Levels Correlate With the Resistance of BALB/cj Mice to Acute Infection. Parasitol Res (1992) 78:215-21. doi: 10.1007/BF00931729

180. Waghabi MC, Coutinho CM, Soeiro MN, Pereira MC, Feige JJ, Keramidas $\mathrm{M}$, et al. Increased Trypanosoma Cruzi Invasion and Heart Fibrosis Associated With High Transforming Growth Factor Beta Levels in Mice Deficient in Alpha(2)-Macroglobulin. Infect Immun (2002) 70:5115-23. doi: 10.1128/IAI.70.9.5115-5123.2002

181. Toppel AW, Rasmussen M, Rohde M, Medina E, Chhatwal GS. Contribution of Protein G-Related Alpha2-Macroglobulin-Binding Protein to Bacterial Virulence in a Mouse Skin Model of Group A Streptococcal Infection. J Infect Dis (2003) 187:1694-703. doi: 10.1086/375029

182. Nyberg P, Rasmussen M, Bjorck L. Alpha2-Macroglobulin-Proteinase Complexes Protect Streptococcus Pyogenes From Killing by the
Antimicrobial Peptide LL-37. J Biol Chem (2004) 279:52820-3. doi: $10.1074 / j b c . C 400485200$

183. Chen CH, Zhang XQ, Lo CW, Liu PF, Liu YT, Gallo RL, et al. The Essentiality of Alpha-2-Macroglobulin in Human Salivary Innate Immunity Against New H1N1 Swine Origin Influenza A Virus. Proteomics (2010) 10:2396-401. doi: 10.1002/pmic.200900775

184. Schramm W, Seitz R, Gurtler L. COVID-19-Associated CoagulopathyHypothesis: Are Children Protected Due to Enhanced Thrombin Inhibition by Higher Alpha2 -Macroglobulin Macroglobulin (Alpha2-M)? J Thromb Haemost (2020) 18:2416-8. doi: 10.1111/jth.15013

185. Seitz R, Gurtler L, Schramm W. Thromboinflammation in COVID-19: Can Alpha2 -Macroglobulin Help to Control the Fire? J Thromb Haemost (2021) 19:351-4. doi: 10.1111/jth.15190

186. Metzemaekers M, Cambier S, Blanter M, Vandooren J, de Carvalho AC, Malengier-Devlies B, et al. Kinetics of Peripheral Blood Neutrophils in Severe Coronavirus Disease 2019. Clin Transl. Immunology (2021) 10:e1271. doi: $10.1002 / \mathrm{cti2} .1271$

187. Vanheule V, Metzemaekers M, Janssens R, Struyf S, Proost P. How PostTranslational Modifications Influence the Biological Activity of Chemokines. Cytokine (2018) 109:29-51. doi: 10.1016/j.cyto.2018.02.026

188. Vandevyver S, Dejager L, Vandenbroucke RE, Libert C. An Acute Phase Protein Ready to Go Therapeutic for Sepsis. EMBO Mol Med (2014) 6:2-3. doi: $10.1002 / \mathrm{emmm} .201303524$

189. Cianciolo GJ, Enghild JJ, Pizzo SV. Covalent Complexes of Antigen and Alpha(2)-Macroglobulin: Evidence for Dramatically-Increased Immunogenicity. Vaccine (2001) 20:554-62. doi: 10.1016/s0264-410x(01) 00361-9

190. Vandendriessche S, Cambier S, Proost P, Marques PE. Complement Receptors and Their Role in Leukocyte Recruitment and Phagocytosis. Front Cell Dev Biol (2021) 9:624025. doi: 10.3389/fcell.2021.624025

Conflict of Interest: The authors declare that the research was conducted in the absence of any commercial or financial relationships that could be construed as a potential conflict of interest.

Publisher's Note: All claims expressed in this article are solely those of the authors and do not necessarily represent those of their affiliated organizations, or those of the publisher, the editors and the reviewers. Any product that may be evaluated in this article, or claim that may be made by its manufacturer, is not guaranteed or endorsed by the publisher.

Copyright $\odot 2021$ Vandooren and Itoh. This is an open-access article distributed under the terms of the Creative Commons Attribution License (CC BY). The use, distribution or reproduction in other forums is permitted, provided the original author(s) and the copyright owner(s) are credited and that the original publication in this journal is cited, in accordance with accepted academic practice. No use, distribution or reproduction is permitted which does not comply with these terms. 


\section{GLOSSARY}

\begin{tabular}{|c|c|}
\hline A2M & alpha-2-macroglobulin \\
\hline A2ML1 & A2M-like-1 \\
\hline AA & arachidonic acid \\
\hline ADAM17 & a disintegrin and metalloprotease 17 \\
\hline ANA & anaphylatoxin domain \\
\hline ApoE & apolipoprotein E \\
\hline $\mathrm{BiP}$ & binding immunoglobulin protein \\
\hline $\mathrm{BRD}$ & bait-region domain \\
\hline C345C & C-terminal extension of C3-5 \\
\hline Uegf & Bmp1 \\
\hline cAMP & cyclic adenosine monophosphate \\
\hline CatG & cathepsin G \\
\hline CLP & cecal ligation puncture \\
\hline $\operatorname{cox} 2$ & cyclooxygenase-2 \\
\hline cPLA2 & cytosolic phospholipase A2 \\
\hline $\mathrm{CR}$ & complement-type repeats \\
\hline CUB & complement $\mathrm{C} 1 \mathrm{r} / \mathrm{C} 1 \mathrm{~s}$ \\
\hline CXCR2 & C-X-C motif chemokine receptor 2 \\
\hline FGF & fibroblast growth factor \\
\hline DAB1 & Disabled homolog 1 \\
\hline DAG & diacyl glycerol \\
\hline GPI & glycosyl-phosphatidyl-inositol linker \\
\hline GRAB & G-related A2M-binding protein \\
\hline GRK2 & G-protein-coupled receptor kinase 2 \\
\hline GRP & cell surface glucose-regulated protein \\
\hline HEL & hen egg lysozyme \\
\hline HSP70 & heat shock protein 70 \\
\hline IL & interleukin \\
\hline IP3 & inositol trisphosphate \\
\hline JDP & $\mathrm{J}$ domain protein \\
\hline JIP & C-Jun-amino-terminal kinase-interacting protein \\
\hline JNK & C-Jun N-terminal kinases \\
\hline LysoPC & lysophosphatidylcholine \\
\hline LRP-1 & low density lipoprotein receptor-related protein-1 \\
\hline MA & methylamine \\
\hline MAC & macroglobulin activated for cytokine binding \\
\hline
\end{tabular}

(Continued)
Continued

\begin{tabular}{|c|c|}
\hline MAPK & mitogen-activated protein kinases \\
\hline MASP & mannose-binding protein-associated serine protease \\
\hline MBP & mannose-binding protein \\
\hline MBL & mannose-binding lectin \\
\hline MG & macroglobulin-like domain \\
\hline MMP & matrix metalloproteinase \\
\hline MT1-MMP & membrane-type 1 matrix metalloproteinase \\
\hline NE & neutrophil elastase \\
\hline$N F-\kappa B$ & nuclear factor kappa-light-chain-enhancer of activated B cells \\
\hline NGF & nerve growth factor \\
\hline NMDA & N-methyl-D-aspartate \\
\hline OA & osteoarthritis \\
\hline P3 & proteinase 3 \\
\hline p75NTR & p75 neurotrophin receptor \\
\hline PAK2 & p21-activated protein kinase-2 \\
\hline PDGF & platelet-derived growth factor \\
\hline PGE2 & prostaglandin E2 \\
\hline PLC $\gamma 1$ & phospholipase $\mathrm{C} \gamma 1$ \\
\hline PSA & prostate-specific antigen \\
\hline PSD & post synaptic density protein \\
\hline PTB & phosphotyrosine-binding \\
\hline PTGS2 & prostaglandin-endoperoxide synthase-2 \\
\hline RA & rheumatoid arthritis \\
\hline RAP & receptor-associated protein \\
\hline RBD & receptor binding domain \\
\hline RhoA & Ras homolog family member $\mathrm{A}$ \\
\hline Sh2 & Src homology 2 \\
\hline SHP-2 & Sh2-containing protein tyrosine phosphatase 2 \\
\hline ROS & reactive oxygen species \\
\hline SMCs & smooth muscle cells \\
\hline TED & thioester domain \\
\hline TEP & thioester-containing protein \\
\hline TGF & transforming growth factor \\
\hline TNF & tumor necrosis factor \\
\hline trk & tyrosine receptor kinase \\
\hline tPA & tissue plasminogen activator \\
\hline VEGF & vascular endothelial growth factor \\
\hline
\end{tabular}

